\title{
Synthesis, $X$-ray diffraction study and pharmacological evaluation of 3-amino-4-methylthiophene-2-acylcarbohydrazones
}

\author{
SONJA HERRMANN ${ }^{1,3}$, TABEA SCHÜBEL ${ }^{1,3}$, FANNY N. COSTA ${ }^{2}$, MARIA LETÍCIA C. BARBOSA ${ }^{1}$, \\ FABIO F. FERREIRA ${ }^{2}$, THAYS L.M.F. DIAS ${ }^{4}$, MORGANA V. ARAÚJO ${ }^{4}$, MAGNA S. ALEXANDRE- \\ MOREIRA ${ }^{4}$, LÍDIA M. LIMA ${ }^{1}$, STEFAN LAUFER ${ }^{3}$ and ELIEZER J. BARREIRO ${ }^{1}$ \\ ${ }^{1}$ Laboratório de Avaliação e Síntese de Substâncias Bioativas/LASSBio ${ }^{\circledR}$, Universidade Federal do Rio de \\ Janeiro/UFRJ, Av. Carlos Chagas Filho, 373, Caixa Postal 68024, 21944-971 Rio de Janeiro, RJ, Brazil \\ ${ }^{2}$ Centro de Ciências Naturais e Humanas/CCNH, Universidade Federal do ABC/ \\ UFABC, Av. dos Estados, 5001, 09210-580 Santo André, SP, Brazil \\ ${ }^{3}$ Department of Pharmaceutical/Medicinal Chemistry, Institute of Pharmacy, Eberhard-Karls- \\ University Tübingen, Av. Auf der Morgenstelle, 8, D-72076 Tübingen, Germany \\ ${ }^{4}$ Laboratório de Farmacologia e Imunidade/LaFI, Instituto de Ciências Biológicas e da Saúde, Universidade Federal \\ de Alagoas/UFAL, Av. Lourival Melo Mota, s/n, Cidade Universitária, 57020-720 Maceió, AL, Brazil
}

Manuscript received on October 8, 2017; accepted for publication on October 30, 2017

\begin{abstract}
$\mathrm{N}$-acylhydrazone is an interesting privileged structure that has been used in the molecular design of a myriad of bioactive compounds. In order to identify new antinociceptive drug candidates, we described herein the design, synthesis, X-ray diffraction study and the pharmacological evaluation of a series of 3-amino-4-methylthiophene-2-acylcarbohydrazone derivatives (8a-t). Compounds were prepared in good overall yields through divergent synthesis from a common key intermediate and were characterized by classical spectroscopy methods. X-ray diffraction study was employed for unequivocal determination of the imine double bond stereochemistry. 8a-t were evaluated in vivo through oral administration using the classical writhing test in mice. $N$-acylhydrazone derivatives $\mathbf{8 j}$ and $\mathbf{8} \mathbf{I}$ displayed relative potency similar to dipyrone, highlighting them as promising analgesic lead-candidates for further investigation.
\end{abstract}

Key words: N-acylhydrazone, privileged structure, antinociceptive, p38MAPK, X-ray.

\section{INTRODUCTION}

The original definition of a privileged scaffold dates back to the year 1988 and was first described

Correspondence to: Stefan Laufer

E-mail: stefan.laufer@uni-tuebingen.de

Eliezer J. Barreiro

E-mail: ejbarreiro@ccsdecania.ufrj.br

* Contribution to the centenary of the Brazilian Academy of Sciences. by Evans and coworkers (Evans et al. 1988). This concept refers to a single molecular framework, correlated to a minimum structural subunit, which affects more than one bioreceptor or enzyme target. The adequate functionalization allows the modulation of the different biological activities and of the selectivity. Rational employment of molecular modification strategies, such as molecular hybridization, bioisosterism, molecular simplification, homologation and conformational 
restriction are applied to adapt and adjust the selected scaffold to the desired pharmacological application. These structural modifications lead to different patterns of lipophilic/hydrophilic nature, H-bonding donor/acceptor properties, electron donating/withdrawing profile, acid/basic character and conformational behavior of the pharmacophoric groups. On the other hand, the previously described synthetic accessibility and the possibility of rational modifications offer access to a wide range of applications for these molecular frameworks, representing an opportunity for rapid, economic and optimized discovery of new drug candidates (Duarte et al. 2007, Evans et al. 1988, Jones 2017).

A well-known example of a privileged structure is the imidazole scaffold. This heterocyclic ring is found in bioactive compounds affecting a wide range of targets, e.g. cimetidine, a H1-receptor antagonist; losartan, an AT1-receptor antagonist; clotrimazole, an antifungal agent; metronidazole, an antimicrobial drug; mercaptopurine, a purine nucleoside antimetabolite; and theophylline, a nonselective phosphodiesterase inhibitor and nonselective adenosine receptor antagonist (Duarte et al. 2007).

Lately, the N-acylhydrazone (NAH; Figure 1) scaffold has been also described as an interesting privileged structure. This chemical framework has been used in the design of several bioactive compounds for treatment of infections (Gu et al. 2012, He et al. 2017, Hernández et al. 2013, Jin et al. 2010, Palace-Berl et al. 2013), schizophrenia (Cutshall et al. 2012, Gage et al. 2011), cancer (Abdel-Aziz et al. 2012, de Figueiredo et al. 2017, Zhai et al. 2013), hypertension (Kümmerle et al. 2009), diabetes (Hernández-Vázquez et al. 2016), nociception and inflammatory disorders (Azizian et al. 2016, Jagtap et al. 2011, Khalil et al. 2013, Ozadali et al. 2012, Ünsal-Tan et al. 2010). The biological versatility of the NAH moiety and its easy synthetic accessibility make it a simple and unique privileged scaffold to be explored in Medicinal Chemistry (Duarte et al. 2007).

Among the biological activities described for NAH derivatives, the analgesic and antiinflammatory properties are noteworthy. Several NAH compounds are well-known inhibitors of relevant inflammation targets, including cyclooxygenases (COX) (Gundogdu-Hizliates et al. 2014, Ünsal-Tan et al. 2010), inducible nitric oxide synthase (iNOS) (Moldovan et al. 2011, Tiperciuc et al. 2013) and the p38 mitogenactivated protein kinase (p38 MAPK) (Lacerda et al. 2012). Examples of promising analgesic and anti-inflammatory NAH lead candidates (1-7) are depicted in Figure 1, highlighting the 3-aminothiophene-2-acylhydrazone derivatives (7a and $7 \mathbf{b}$ ), which have recently been described by our research group as non-toxic, analgesic and antiinflammatory candidates (Da Silva et al. 2014).

We described herein the synthesis, X-ray diffraction study and in vivo and in vitro pharmacological evaluation of new 3-amino-4methylthiophene-2-acylcarbohydrazones (8a-t), designed by the introduction of a methyl group at position 4 of the thiophene ring in order to explore the methylation effect (Barreiro et al. 2011) in the biological profile of this new series of NAH derivatives (Figure 2). Moreover, the design concept explored the possibility to employ the same starting material used in the synthesis of the local anesthetic articaine (i.e. methyl 3-amino-4methylthiophene-2-carboxylate, 9) (Li et al. 2013), already known as a safe structural framework, contributing to the synthetic accessibility and druglike properties of the NAHs (8a-t) described here.

\section{MATERIALS AND METHODS}

\section{CHEMISTRY}

All commercially available reagents and solvents were used without further purification. Reactions were routinely monitored by thin- 


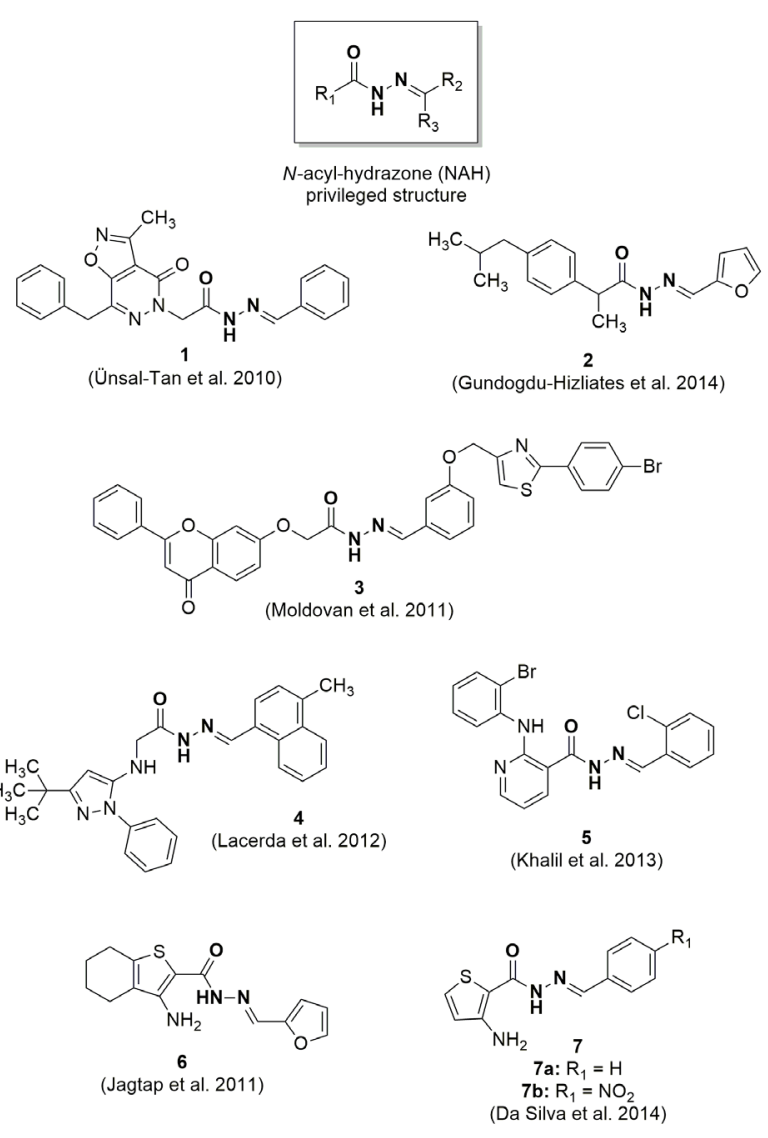

Figure 1 - Analgesic and anti-inflammatory drug candidates presenting the privileged $\mathrm{N}$-acyl-hydrazone (NAH) structure.

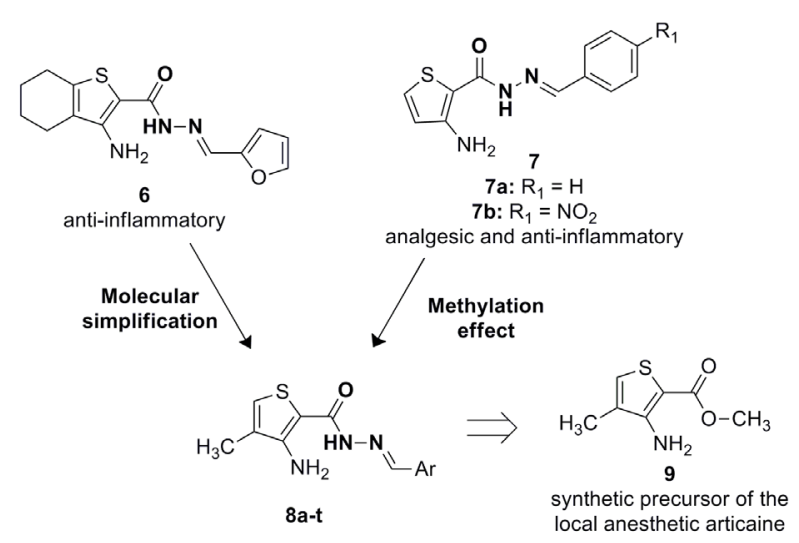

Figure 2 - Design concept of the $N$-acyl-hydrazone (NAH) derivatives $(\mathbf{8 a - t})$. layer chromatography (TLC) in silica gel plates (KieselGel 60 F254 Merck). The mobile phase consisted of a mixture of $70 \%$ hexane $/ 30 \%$ ethyl acetate or $95 \%$ dichloromethane $/ 5 \%$ methanol. The developed plates were examined with UV lamps (in wavelength of $254 \mathrm{~nm}$ and $365 \mathrm{~nm}$ ) or by employing the color reagents iodine, 2,4-dinitrophenylhydrazine (coloring ketones or aldehydes) or 4-dimethylaminobenzaldehyde (highlighting amines). The melting points (m.p.) of the final products were determined by differential scanning calorimetry (DSC) using a Shimadzu DSC-60, with a heating rate of $20^{\circ} \mathrm{C} / \mathrm{min}$ and a maximum temperature of $300{ }^{\circ} \mathrm{C}$. The results were recorded as the onset temperatures (Tonset), which are defined as the point of intersection of the tangent of the peak with the extrapolated baseline. The apparatus DSC-60 was calibrated with indium (In, m.p. $157^{\circ} \mathrm{C}$ ).

Mass spectrometry (MS) was performed by positive ionization at Bruker AmaZon SL. EI-ion-trap MS (electrospray ionization ion trap mass spectrometry) and the data were analyzed by Compass 4.0 software. The relative purity of the final compounds (8a-t) was determined by high performance liquid chromatography (HPLC) using a Shimadzu apparatus- LC20AD, column Kromasil 100-5 C18 (4.6 mm x $250 \mathrm{~mm}$ ) and detector SPDM20A (Diode Array) in the substance-specific wavelength (240-370 nm), employing a constant flux of $1 \mathrm{~mL} / \mathrm{min}$ with an injection volume of 20 $\mu \mathrm{L}$. A mixture of $70 \%$ methanol $/ 30 \%$ water (A) or $80 \%$ methanol $/ 20 \%$ water (B) was used as solvent. Standard HPLC solvents were purchased from TEDIA ${ }^{\circledR}$. Data were acquired by software "LC solution" version 4.0. Infrared (IR) spectra were obtained using a Thermo Nicolet IS 10 FTIR spectrometer equipped with smart iTR ATR accessory for direct measurements.

The ${ }^{1} \mathrm{H}$ and ${ }^{13} \mathrm{C}$ nuclear magnetic resonance spectra were determined in DMSO- $d_{6}$ solutions using a Bruker AC-200 spectrometer with 200 
$\mathrm{MHz}$ for ${ }^{1} \mathrm{H}$ and $50 \mathrm{MHz}$ for ${ }^{13} \mathrm{C}$ (LABRMN, UFRJ). The chemical shifts are given in parts per million $(\delta)$ from solvent residual peaks and the coupling constant values (J) are given in $\mathrm{Hz}$. Signal multiplicities are represented by: s (singlet), d (doublet), $\mathrm{t}$ (triplet) and $\mathrm{m}$ (multiplet). The synthetic methodologies and the detailed structure analysis for the target compounds (8a-t) are described in the Experimental Section.

\section{X-RAY DIFFRACTION STUDY}

In order to obtain a good X-ray powder diffraction (XRPD) pattern, the sample preparation is an important step. The selected compound $\mathbf{8 j}$ was gently hand-grinded using a pestle and an agate mortar. The measurement was carried out at room temperature on a STADI-P powder diffractometer (Stoe ${ }^{\circledR}$, Darmstadt, Germany) using transmission geometry with $\mathrm{CuK}_{\alpha 1}(\lambda=1.54056 \AA)$ radiation. The wavelength was selected by a curved Ge (111) crystal, with a tube voltage of $40 \mathrm{kV}$ and a current of $40 \mathrm{~mA}$. The fine powdered sample was loaded into a $0.3 \mathrm{~mm}$ diameter special glass capillary $\mathrm{nr}$. 14 (Hilgenberg ${ }^{\circledR}$, Malsfeld, Germany), which was kept spinning during data collection. A Mythen $1 \mathrm{~K}$ (Dectris $^{\circledR}$, Baden, Switzerland) linear detector was used and the reflections were detected in the range from $3^{\circ}$ to $61.785^{\circ}$, with step sizes of $0.015^{\circ}$ and $600 \mathrm{~s}$ of integration time at each $1.05^{\circ}$.

On the basis of previous procedures (Costa et al. 2015, 2013), the crystal structure of $\mathbf{8 j}$ was determined using the DASH software program (David et al. 2006). Topas-Academic v.5 (Coelho et al. 2011) was used to index the diffraction pattern as well as to refine the crystal structure.

\section{BIOLOGICAL ASSAYS}

\section{Acetic acid-induced writhing test}

Nociception was induced by the i.p. injection of acetic acid $(0.6 \%, \mathrm{v} / \mathrm{v} ; 0.1 \mathrm{~mL} / 10 \mathrm{~g}$ body weight).
The number of writhes, a response consisting of the contraction of the abdominal wall and pelvic rotation, followed by hind-limb extension, was counted during continuous observation for $20 \mathrm{~min}$, beginning $5 \mathrm{~min}$ after the acetic acid injection. NAH derivatives 8a-t (100 $\mu \mathrm{mol} / \mathrm{kg}$, oral administration) were administered 40 min before the acetic acid injection. The control group received $10 \mathrm{~mL} / \mathrm{kg}$ of the vehicle (distilled water with $20 \mu \mathrm{L}$ of Tween 80) via the i.p. route. Antinociceptive activity was expressed as percentage of inhibition of the usual number of writhing observed in control animals (Collier et al. 1968). The Research Ethics Committee from the Federal University of Alagoas (UFAL) approved the animal experimental model presented in this study and the process protocol number is $n^{0} 55 / 2013$.

\section{p38 MAPK inhibition assay}

The experimental settings and screening procedures of the employed nonradioactive immunosorbent p38 $\alpha$ mitogen-activated protein kinase (p38a MAPK) activity assay have previously been described (Goettert et al. 2010). The ELISA assay was performed using 96-well plates (Nunc MaxiSorp ${ }^{\circledR}$, Fisher Scientific), which were coated with $50 \mu \mathrm{L} /$ well $(10 \mu \mathrm{g} / \mathrm{mL})$ in Tris-buffered saline (TBS) of the p38 $\alpha$ substrate ATF-2 (ProQinase, Freiburg, Germany) and stored overnight at $4{ }^{\circ} \mathrm{C}$. Subsequently, each plate was washed three times with bi-distilled water and remaining binding sites were blocked with blocking buffer (BB: $0.05 \%$ Tween 20, $0.025 \%$ bovine serum albumin (BSA) and $0.02 \% \mathrm{NaN}_{3}$ in TBS) for 30 minutes at room temperature and washed again three times. A 10 $\mathrm{mM}$ stock solution of samples was prepared in dimethyl sulfoxide and further diluted in a kinase buffer (KB), which contained $12 \mathrm{ng} / 50 \mu$ Lactivated p38 a MAPK (Prof. Dr. J. Schultz, University of Tübingen, Germany), $50 \mathrm{mM}$ Tris of $\mathrm{pH} 7.5,10$ $\mathrm{mM} \mathrm{MgCl}, 10 \mathrm{mM} \beta$-Glycerolphosphate, $100 \mu \mathrm{g} /$ 
mL BSA, $1 \mathrm{mM}$ Dithiothreitol, $0.1 \mathrm{mM} \mathrm{Na} \mathrm{VO}_{4}$, and $100 \mu \mathrm{M}$ ATP were used to dilute the samples and as control. $50 \mu \mathrm{L}$ of each dilution (0.01-10 $\mu \mathrm{M})$ was pipetted into the corresponding wells and incubated 1 hour at $37^{\circ} \mathrm{C}$. After washing this dilution three times with bi-distilled water, blocking it for 15 minutes and washing it three more times, the $50 \mu \mathrm{L}$ of diluted monoclonal anti-phosphoATF-2 (Thyr69/71) peroxidase-conjugated antibody (1:5000) (Sigma, Germany) in blocking buffer adjusted to a $\mathrm{pH}$ of 6.5 was added into each well and incubated for 1 hour at $37{ }^{\circ} \mathrm{C}$, followed by adding $50 \mu \mathrm{L}$ of 3,3',5,5'-tetramethylbenzidine (TMB) (BD Bioscience, Europe) substrate into all wells. Then, the peroxide-labeled conjugates developed a definitive blue color, which was measured photometrically at $650 \mathrm{~nm}$ or was read at $450 \mathrm{~nm}$ with an ELISA reader (SOFTmax PRO software) after stopping with $25 \mu \mathrm{L}$ of $2 \mathrm{~N} \mathrm{H}_{2} \mathrm{SO}_{4}$. The inhibitor SB 203580 (Laboratory Prof. Dr. S.A. Laufer, University of Tübingen, Germany) was used as reference.

\section{RESULTS AND DISCUSSION}

\section{CHEMISTRY}

The designed 3-amino-4-methylthiophene-2acylcarbohydrazones (8a-t) were synthesized efficiently via divergent synthesis as outlined in Figure 3. Starting from the synthetic precursor methyl 3-amino-4-methylthiophene-2carboxylate (9), the key intermediate 3 -amino4-methylthiophene-2-carbohydrazide (10) was prepared by hydrazinolysis reaction. With intermediate $\mathbf{1 0}$ in hands, the NAH derivatives 8a-t were obtained by classical condensation with functionalized aldehydes under acid catalysis (Da Silva et al. 2014, Lacerda et al. 2012). The target compounds (8a-t) were prepared in good yields, between 42.4 and $95.5 \%$, and were analyzed by HPLC, MS, IR, ${ }^{1} \mathrm{H}-\mathrm{NMR}$ and ${ }^{13} \mathrm{C}-\mathrm{NMR}$. Analytical data were in full agreement with the proposed structures.

It's relevant to mention that NAHs may exist as $E / Z$ geometrical isomers regarding the $-\mathrm{C}=\mathrm{N}$ double bond configuration, and may be observed as cis/trans amide (-CO-NH-) conformers (AbdelAziz et al. 2012, Khalil et al. 2013). To address this subject a careful analysis of the ${ }^{1} \mathrm{H}-\mathrm{NMR}$ signals recorded for compounds 8a-t in DMSO- $d_{6}$ was conducted. Only one single signal related to the imine hydrogen $(\mathrm{CH}=\mathrm{N})$ was detected, with chemical displacement varying between $7.81 \mathrm{ppm}$ and $8.21 \mathrm{ppm}$. These data indicate that the NAH derivatives 8a-t were synthesized in just one geometrical isomer. Based on chemical shifts of $E / Z$-isomer reported in literature (Palla et al. 1982), compounds 8a-t were assumed to have the $E$ configuration for their imine double bond. To confirm this assumption, XRPD studies were performed using compound $\mathbf{8 j}$ as a model. As depicted in Figure 4, the crystal structure of $8 \mathbf{j}$ is arranged in a monoclinic space group $(C c)$, with unit cell dimensions $a=38.971(6) \AA, b=$ 4.8314(6) $\AA, c=18.843(2) \AA, \beta=109.964(4)^{\circ}$ and $V=3334.6(8) \AA^{3}$. The goodness of fit indicator and $R$-factors were, respectively: $\chi^{2}=3.153, R_{\exp }$ $=1.166 \%, R_{\text {wp }}=3.675 \%$ and $R_{\text {Bragg }}=2.945 \%$. The crystal structure of compound $\mathbf{8 j}$ is comprised by eight formula units per unit cell $(Z=8)$, accommodating two molecules in the asymmetric unit $\left(Z^{\prime}=2\right)$. The relative configuration $E$ about the imine double bond was observed, corroborating with the assignment based on NMR shifts. Regarding the conformation of the amide subunit $(\mathrm{CONH}), \mathrm{X}$-ray powder diffraction studies revealed a cis-conformation in the crystal structure of $\mathbf{8 j}$. The hydrogen inter/intramolecular interactions contribute to the organization of the space arrangement in the unit cell. The intermolecular interactions can be observed between atoms $\mathrm{N}(9)-\mathrm{H}(55) \cdots \mathrm{O}(34)(\mathrm{D}-\mathrm{H}=0.9 \AA, \mathrm{H} \cdots \mathrm{A}=2.4 \AA$, $\mathrm{D} \cdots \mathrm{A}=3.2 \AA$ and $\left.\mathrm{D}-\mathrm{H} \cdots \mathrm{A}=144^{\circ}\right)$ and $\mathrm{N}(33)$ 


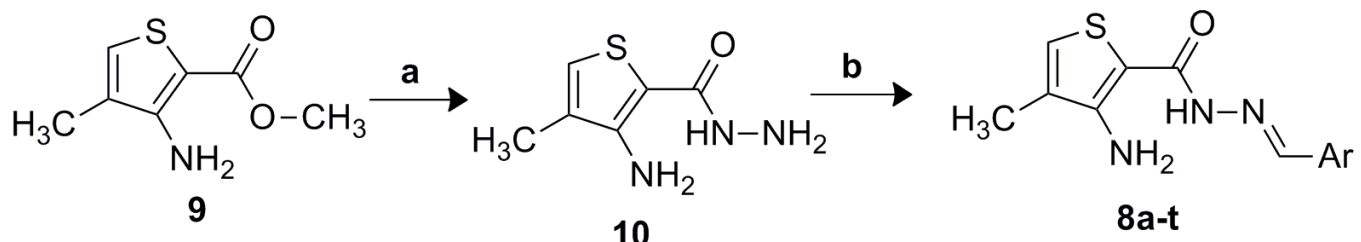
key intermediate
8a: $A r=P h$
8k: $A r=$ naphthalen-1-yl
8b: $\mathrm{Ar}=4-\mathrm{Br}-\mathrm{C}_{6} \mathrm{H}_{4}$
8c: $\mathrm{Ar}=4-\mathrm{NO}_{2}-\mathrm{C}_{6} \mathrm{H}_{4}$
8d: $\mathrm{Ar}=4-\mathrm{OH}-\mathrm{C}_{6} \mathrm{H}_{4}$
8e: $\mathrm{Ar}=4-\mathrm{CO}_{2} \mathrm{H}-\mathrm{C}_{6} \mathrm{H}_{4}$
8f: $\quad \mathrm{Ar}=4-\mathrm{N}\left(\mathrm{CH}_{3}\right)_{2}-\mathrm{C}_{6} \mathrm{H}_{4}$
8I: $\quad A r=$ naphthalen-2-yl
8m: $A r=$ ferrocenyl
8n: $A r=$ furan-2-yl
8g: $\mathrm{Ar}=4-\mathrm{OCH}_{3}-\mathrm{C}_{6} \mathrm{H}_{4}$
8o: $A r=$ furan-3-yl
8h: $\mathrm{Ar}=4-\mathrm{iPr}-\mathrm{C}_{6} \mathrm{H}_{4}$
8i: $\quad \mathrm{Ar}=4-\mathrm{OPh}-\mathrm{C}_{6} \mathrm{H}_{4}$
8p: $A r=$ pyrrol-2-yl
8q: $A r=$ thiophen-2-yl
8j: $\quad \mathrm{Ar}=4$-biphenyl
8r: $A r=$ thiophen-3-yl
8s: $A r=$ pyridin-3-yl
8t: $\quad A r=$ pyridin-4-yl

Figure 3 - General methodology for synthesis of 3-amino-4-methylthiophene-2-acylcarbohydrazones 8a-t. Reagents and Conditions: a) $\mathrm{N}_{2} \mathrm{H}_{4} \mathrm{H}_{2} \mathrm{O}(80 \%)$, EtOH, $80{ }^{\circ} \mathrm{C}$, reflux, 80 h, 74.1\%; b) $\mathrm{ArCHO}$, EtOH, $\mathrm{HCl}$ (cat), r.t., 0.5-3.5 h, 42.4-95.5\%.

$\mathrm{H}(72) \cdots \mathrm{O}(10)(\mathrm{D}-\mathrm{H}=0.9 \AA, \mathrm{H} \cdots \mathrm{A}=2.3 \AA, \mathrm{D} \cdots \mathrm{A}$ $=3.1 \AA$ and $\mathrm{D}-\mathrm{H} \cdots \mathrm{A}=147^{\circ}$ ), where " $\mathrm{D}$ " and " $\mathrm{A}$ " are, respectively, hydrogen donor and acceptor. For the intramolecular interactions the involved atoms are $\mathrm{N}(4)-\mathrm{H}(49) \cdots \mathrm{O}(10)(\mathrm{D}-\mathrm{H}=0.9 \AA, \mathrm{H} \cdots \mathrm{A}=2.1$ $\AA, \mathrm{D} \cdots \mathrm{A}=2.7 \AA$ and $\mathrm{D}-\mathrm{H} \cdots \mathrm{A}=133^{\circ}$ ) and $\mathrm{N}(28)$ $\mathrm{H}(66) \cdots \mathrm{O}(34)$ with a distance $\mathrm{D}-\mathrm{H}=0.9 \AA, \mathrm{H} \cdots \mathrm{A}$ $=2.0 \AA, \mathrm{D} \cdots \mathrm{A}=2.7 \AA$ and $\mathrm{D}-\mathrm{H} \cdots \mathrm{A}=129^{\circ}$. All interactions are represented by cyan lines in Fig. 4. Supplementary crystallographic data can be found on the Cambridge Crystallographic Data Centre web site (www.ccdc.cam.ac.uk/data_request/cif) searching for CCDC ID: 1576495.

\section{PHARMACOLOGICAL EVALUATION}

Considering the previously described analgesic and anti-inflammatory properties of 3-aminothiophene2-acylhydrazones $\mathbf{7 a}$ and $\mathbf{7 b}$ (Da Silva et al. 2014), we decided in a first approach to study the antinociceptive profiles of the methylated analogues 8a-t using the classical writhing test. In this animal model, peripheral pain is induced in mice by a parenteral administration of acetic acid. Consequently, signals are sent to the central nervous system, causing release of several mediators, including prostaglandins, which contribute to increased sensitivity of nociceptors. As summarized in Table I, the 3-amino-4methylthiophene-2-acylcarbohydrazones 8a-t were evaluated in a screening dose of $100 \mu \mathrm{mol} / \mathrm{kg}$ by oral administration, using dipyrone as standard.

Among all evaluated compounds, ten derivatives (8b, 8c, 8d, 8f, 8h, 8i, 8m, 8p, 8s and 8t) were inactive in comparison to control, not being able to reduce the amount of constrictions. 8e, 80 and $8 r$ presented weak inhibitory activity, whereas $\mathbf{8 a}, \mathbf{8 g}, \mathbf{8 k}, \mathbf{8 n}$ and $\mathbf{8 q}$ showed moderate antinociceptive effect at this dose. Explicitly, two derivatives ( $\mathbf{8} \mathbf{j}$ and $\mathbf{8 1}$ ) demonstrated an expressive antinociceptive activity at the evaluated dose, with $70.0 \%$ and $70.2 \%$ of inhibition, comparable to the inhibition found for the standard dipyrone.

In comparison to the non-methylated original analgesic and anti-inflammatory prototypes $7 \mathbf{a}(\mathrm{Ar}$ $=$ phenyl; $\mathrm{ID}_{50}=3,5 \mu \mathrm{mol} / \mathrm{kg}$ in acetic acid-induced writhing model, p.o.) and $\mathbf{7 b}(\mathrm{Ar}=4$-nitro-phenyl; $\mathrm{ID}_{50}=2,6 \mu \mathrm{mol} / \mathrm{kg}$ in acetic acid-induced writhing model, p.o.) (Da Silva et al. 2014), the methylation effect was deleterious for the antinociceptive profile of the methylated counterparts 8a $(\mathrm{Ar}=$ phenyl) and 8c (Ar = 4-nitro-phenyl). On the other hand, regarding the aromatic ring linked to the imine 


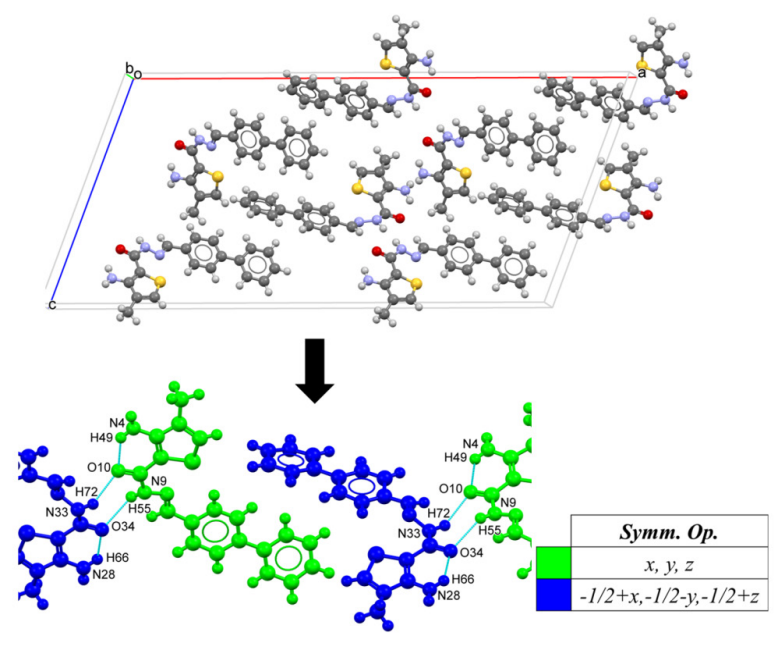

Figure 4 - (Top) Unit cell representation of compound $\mathbf{8 j}$ recognized by X-ray powder diffraction. (Bottom) The hydrogen inter/intramolecular interactions between the atoms from different equivalent symmetry operations are displayed in cyan lines.

carbon, the introduction of more hydrophobic and bulky aromatic systems such as 4-biphenyl (8j) and 2-naphthyl (81), not yet explored for the previously described 3-aminothiophene-2-acylhydrazones, proved to be useful for the optimization of the antinociceptive effect within the series.

Particularly, the p38 mitogen-activated protein kinase (p38 MAPK) plays a key role in inflammatory disorders, and it has been also implicated in the signal transduction cascade associated with chronic nociception and nociceptive sensitization (Anand et al. 2011, Lin et al. 2014, Zarubin and Han 2005). Our research group already described novel NAH derivatives designed as p38 MAPK inhibitors as orally active anti-inflammatory and antinociceptive drug candidates (Lacerda et al. 2012). Therefore, we also investigated the ability of compounds 8a-t to inhibit the enzymatic activity of p38 $\alpha$ MAPK, using a nonradioactive immunosorbent assay and SB203590 as standard. As depicted in Table I, at the screening concentration of $10 \mu \mathrm{M}$, NAH derivatives 8a-t revealed weak p38 $\alpha$ inhibition or were totally inactive. Although compounds 8a, 8d, 8m, 8q, $\mathbf{8 s}$ and $\mathbf{8 t}$ presented inhibitory percentages above
$30 \%$, none of the investigated NAH derivatives reached an inhibitory effect of $50 \%$, indicating $\mathrm{IC}_{50}$ values above the tested concentration of $10 \mu \mathrm{M}$. Moreover, no correlation was observed between the in vivo antinociceptive activities and the in vitro p38 MAPK inhibitory effect, indicating that this protein kinase is not the main biological target of the 3-amino-4-methylthiophene-2acylcarbohydrazone bioactive analogues, mainly $\mathbf{8 j}$ and $\mathbf{8 1}$.

\section{CONCLUSIONS}

In an attempt to identify new antinociceptive drug candidates, twenty 3-amino-4-methylthiophene2-acylcarbohydrazones (8a-t) were synthesized in good overall yields and, based on X-ray powder diffraction studies realized with compound $\mathbf{8 j}$, the relative configuration of their imine double bond was elucidated. Moreover, these studies revealed a cis-conformation for the amide subunit in the crystal structure of $\mathbf{8 j}$. The compounds described herein were overall less potent than the nonmethylated original series, with exception of the new NAH derivatives $\mathbf{8 j}$ and $\mathbf{8 1}$, which displayed relative potency similar to dipyrone, a traditional analgesic used worldwide for the treatment of acute and chronic pain. These results suggest that the introduction of more hydrophobic and bulky aromatic systems linked to the imine carbon, such as 4-biphenyl (8j) and 2-naphthyl (81), represents a favorable structural modification for optimization of the antinociceptive effect within the described series.

\section{EXPERIMENTAL SECTION}

SYNTHESIS AND CHARACTERIZATION OF COMPOUNDS

Synthesis of the key intermediate (3-amino-4methylthiophene-2-carbohydrazide, 10)

In a $100 \mathrm{~mL}$ flask equipped with a magnetic stirrer and a reflux condenser, methyl 3-amino-4- 
TABLE I

Effect of the target compounds (8a-t) and dipyrone $(100 \mu \mathrm{mol} / \mathrm{kg}$; p.o.) on the $0.6 \%$ acetic acid-induced abdominal constriction model in mice (period of $25 \mathrm{~min}$ ), and, in the last column, percentage of inhibition of p38a MAPK enzymatic activity for the compounds (8a-t) and positive standard SB-203580 $(10 \mu \mathrm{M})$ in the nonradioactive immunosorbent assay.

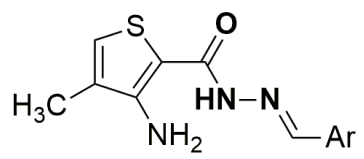

8a-t

\begin{tabular}{|c|c|c|c|c|}
\hline & \multirow[t]{2}{*}{ Compound } & \multicolumn{2}{|c|}{ Abdominal constrictions } & \multirow{2}{*}{$\begin{array}{c}\text { P38aMAPK } \\
\text { Inhibition [\%] }\end{array}$} \\
\hline & & (Mean \pm S.E.M.) & Percentage of Inhibition [\%] & \\
\hline & Control & $28.9 \pm 2.3$ & - & - \\
\hline & Dipyrone & $8.0 \pm 2.4$ & $70.2 * *$ & - \\
\hline & SB 203580 & - & - & 92.1 \\
\hline $8 \mathbf{a}$ & $\mathrm{Ph}$ & $15.2 \pm 2.2$ & $47.4 * *$ & 38.7 \\
\hline $\mathbf{8 b}$ & $4-\mathrm{Br}-\mathrm{C}_{6} \mathrm{H}_{4}$ & $23.4 \pm 6.9$ & - & 23.5 \\
\hline $8 c$ & $4-\mathrm{NO}_{2-} \mathrm{C}_{6} \mathrm{H}_{4}$ & $25.8 \pm 4.2$ & - & 15.2 \\
\hline 8d & $4-\mathrm{OH}-\mathrm{C}_{6} \mathrm{H}_{4}$ & $28.7 \pm 5.2$ & - & 30.8 \\
\hline $8 \mathbf{e}$ & $4-\mathrm{CO}_{2} \mathrm{H}-\mathrm{C}_{6} \mathrm{H}_{4}$ & $16.0 \pm 2.9$ & $40.5^{*}$ & 13.2 \\
\hline $8 f$ & $4-\left[\mathrm{N}\left(\mathrm{CH}_{3}\right)_{2}\right]-\mathrm{C}_{6} \mathrm{H}_{4}$ & $26.7 \pm 2.2$ & - & 5.54 \\
\hline $8 \mathrm{~g}$ & $4-\mathrm{OCH}_{3}-\mathrm{C}_{6} \mathrm{H}_{4}$ & $13.0 \pm 6.2$ & $55.0 * *$ & 4.23 \\
\hline $8 h$ & 4-iPr- $\mathrm{C}_{6} \mathrm{H}_{4}$ & $30.6 \pm 5.2$ & - & 23.4 \\
\hline $8 \mathbf{i}$ & $4-\mathrm{OPh}-\mathrm{C}_{6} \mathrm{H}_{4}$ & $26.0 \pm 3.3$ & - & 28.5 \\
\hline $8 \mathbf{j}$ & 4-biphenyl & $8.8 \pm 3.5$ & $70.0 * * *$ & 26.4 \\
\hline $8 \mathbf{k}$ & naphthalen-1-yl & $12.8 \pm 3.5$ & $55.7 * *$ & 25.1 \\
\hline 81 & naphthalen-2-yl & $8.6 \pm 6.1$ & $70.2 * * *$ & 13.4 \\
\hline $8 m$ & Ferrocenyl & $25.5 \pm 5.4$ & - & 36.4 \\
\hline $8 n$ & furan-2-yl & $12.2 \pm 2.3$ & $57.9 * *$ & 9.19 \\
\hline 80 & furan-3-yl & $19.0 \pm 1.8$ & $34.3^{*}$ & 23.3 \\
\hline $8 p$ & pyrrol-2-yl & $25.0 \pm 1.9$ & - & 28.6 \\
\hline $8 q$ & thiophen-2-yl & $11.0 \pm 5.8$ & $61.9 * *$ & 37.5 \\
\hline $8 r$ & thiophen-3-yl & $16.7 \pm 5.0$ & $42.2 *$ & 22.7 \\
\hline $8 s$ & pyridin-3-yl & $21.4 \pm 2.9$ & - & 32.0 \\
\hline $8 t$ & pyridin-4-yl & $27.0 \pm 3.8$ & - & 32.0 \\
\hline
\end{tabular}

Data are expressed as mean \pm S.E.M. Statistical differences between the treated and the control group were evaluated by ANOVA and Dunnett tests; the asterisks denote the levels of significance in comparison with control groups. ${ }^{*} \mathrm{p}<0.05 ;{ }^{* *} \mathrm{p}<0.01 ;{ }^{* * *} \mathrm{p}<$ 0.001 .

methylthiophene-2-carboxylate (9) (1.02 g; 5.96 $\mathrm{mmol})$ was dissolved in absolute ethanol $(10.0 \mathrm{~mL})$ and heated at $80{ }^{\circ} \mathrm{C}$. Afterwards, an $80 \%$ solution of hydrazine monohydrate $(9.36 \mathrm{~g} ; 3.07 \mathrm{~mL} ; 292$ $\mathrm{mmol}$ ) was slowly added to the reaction medium, which was constantly stirred at $80^{\circ} \mathrm{C}$. The reaction mixture was maintained under reflux for 80 hours, at which time TLC (70\% hexane/30\% ethyl acetate; 4-dimethylaminobenzaldehyde) indicated the end of the reaction. After cooling, reaction media was concentrated under reduced pressure. By adding crushed ice to the flask, the desired carbohydrazide (10) precipitated as yellow crystalline solid and was collected by vacuum filtration. The key 
intermediate $\mathbf{1 0}$ was collected with a yield of 74.1 $\%$. The ${ }^{1} \mathrm{H}$ NMR and ${ }^{13} \mathrm{C}$ NMR data for compound $\mathbf{1 0}$ are consistent with previous reports (Al-Nuri and Husein 2011).

General procedure for synthesis of target compounds $8 \boldsymbol{a}-\boldsymbol{t}$

In a $50 \mathrm{~mL}$ flask equipped with a magnetic stirrer, 3-amino-4-methylthiophene-2-carbohydrazide (10) (0.15-0.30 g; 0.87-1.75 mmol) was dissolved in absolute ethanol $(12.0 \mathrm{~mL})$. Next, the corresponding aldehyde (0.12-0.29 g; 0.97-1.85 mmol) and three drops of hydrochloric acid $37 \%$ were added and the reaction mixture was stirred at room temperature for 0.5-3.5 hours, until TLC examination indicated the end of reaction. Isolation was performed by product precipitation after adding crushed ice to the flask. Products 8a-t were collected by vacuum filtration and purified properly by recrystallization from absolute ethanol if necessary.

(E)-3-amino-N'-benzylidene-4-methylthiophene-2carbohydrazide (8a; LASSBio 1881)

Obtained after 0.5 hour of reaction between the key intermediate $\mathbf{1 0}(0.25 \mathrm{~g} ; 1.46 \mathrm{mmol})$ and benzaldehyde $(0.17 \mathrm{~g} ; 0.16 \mathrm{~mL} ; 1.56 \mathrm{mmol})$ as a yellow crystalline solid. Yield $88.9 \%$; m.p. 202 ${ }^{\circ} \mathrm{C}$; MS (EI) $\mathrm{m} / \mathrm{z}$ calcd for $\mathrm{C}_{13} \mathrm{H}_{13} \mathrm{~N}_{3} \mathrm{OS}(\mathrm{M}+) 259$; found $260(\mathrm{MH}+)$; HPLC $(\mathrm{A}, 342 \mathrm{~nm})=99.2 \%$.

IR (ATR) $\mathbf{v}_{\max }\left(\mathbf{c m}^{-1}\right): 3401\left(v_{\text {as }} \mathrm{NH}_{2}\right) ; 3303$ $\left(v_{\mathrm{s}} \mathrm{NH}_{2}\right) ; 3137(\mathrm{vNH}) ; 3025(\mathrm{vCH}) ; 2925\left(\mathrm{vCH}_{3}\right)$; $1622(v \mathrm{C}=\mathrm{O}) ; 1591(\mathrm{vC}=\mathrm{N}) ; 1555(\delta \mathrm{NH}) ; 1440$ (vCC); $1369(v \mathrm{NH})$.

${ }^{1}$ H NMR (200 MHz, DMSO-d6) $\delta$ (ppm) (Supplementary Material - Figure S1): 2.04 (s, $\left.3 \mathrm{H}, \mathrm{CH}_{3}\right) ; 6.86\left(\mathrm{~s}, 2 \mathrm{H}, \mathrm{NH}_{2}\right) ; 7.31(\mathrm{~s}, 1 \mathrm{H}, \mathrm{H} 5)$; 7.35-7.55 (m, 3H, H3' \& H4' \& H5'); 7.76 (d, 2H, $\mathrm{J}=7.17 \mathrm{~Hz}, \mathrm{H} 2^{\prime}$ \& H6'); 8.02 (s, 1H, N=CH); 11.2 (s, 1H, CONH).

${ }^{13} \mathrm{C}$ NMR (50 MHz, DMSO-d6) $\delta$ (ppm) (Figure S2): $12.8\left(\mathrm{CH}_{3}\right) ; 97.0(\mathrm{C} 2) ; 127$ (C2' \&
C6'); 129 (C3' \& C4' \& C5'); 129 (C4); 130 (C1'); 135 (C5); 142 (C3); $156(\mathrm{~N}=\mathrm{CH}) ; 165(\mathrm{CONH})$.

(E)-3-amino-N'-(4-bromobenzylidene)-4methylthiophene-2-carbohydrazide (8b; LASSBio 1879)

Obtained after 2 hours of reaction between the key intermediate $\mathbf{1 0}(0.20 \mathrm{~g} ; 1.16 \mathrm{mmol})$ and 4-bromobenzaldehyde ( $0.24 \mathrm{~g} ; 1.26 \mathrm{mmol})$ as a yellow crystalline solid. Yield $93.0 \%$; m.p. $250{ }^{\circ} \mathrm{C}$; MS (EI) m/z calcd for $\mathrm{C}_{13} \mathrm{H}_{12} \mathrm{BrN}_{3} \mathrm{OS}(\mathrm{M}+) 337$ and 339; found 338 and $340(\mathrm{MH}+)$; $\operatorname{HPLC}(\mathrm{B}, 342$ $\mathrm{nm})=99.4 \%$.

IR (ATR) $v_{\max }\left(\mathbf{c m}^{-1}\right): 3393\left(\mathrm{v}_{\mathrm{as}} \mathrm{NH}_{2}\right) ; 3293$ $\left(v_{\mathrm{s}} \mathrm{NH}_{2}\right) ; 3137(\mathrm{vNH}) ; 2918\left(\mathrm{vCH}_{3}\right) ; 1622(\mathrm{vC}=\mathrm{O})$; $1591(\mathrm{vC}=\mathrm{N}) ; 1556(\delta \mathrm{NH}) ; 1440(\mathrm{vCC}) ; 1373$ $(v \mathrm{NH}) ; 1061(\mathrm{vCBr})$.

${ }^{1}$ H NMR (200 MHz, DMSO-d6) $\delta$ (ppm): $2.04\left(\mathrm{~s}, 3 \mathrm{H}, \mathrm{CH}_{3}\right) ; 6.87\left(\mathrm{~s}, 2 \mathrm{H}, \mathrm{NH}_{2}\right) ; 7.30(\mathrm{~s}, 1 \mathrm{H}$, H5); 7.50-7.84 (m, 4H, H2' \& H3' \& H5' \& H6'); 7.99 (s, 1H, N=CH); 11.3 (s, 1H, CONH).

${ }^{13} \mathrm{C}$ NMR (50 MHz, DMSO-d6) $\delta$ (ppm): $12.8\left(\mathrm{CH}_{3}\right) ; 96.8$ (C2); 123 (C4'); 127 (C4); 129 (C2' \& C4'); 130 (C1'); 132 (C3' \& C5'); 134 (C5); $141(\mathrm{C} 3) ; 156(\mathrm{~N}=\mathrm{CH}) ; 165(\mathrm{CONH})$.

\section{(E)-3-amino-4-methyl-N'-(4-nitrobenzylidene)} thiophene-2-carbohydrazide (8c; LASSBio 1890)

Obtained after 1.5 hours of reaction between the key intermediate $\mathbf{1 0}(0.25 \mathrm{~g} ; 1.46 \mathrm{mmol})$ and 4-nitrobenzaldehyde $(0.24 \mathrm{~g} ; 1.56 \mathrm{mmol})$ as an orange crystalline solid. Yield 93.5\%; m.p. 297 ${ }^{\circ} \mathrm{C}$; MS (EI) m/z calcd for $\mathrm{C}_{13} \mathrm{H}_{12} \mathrm{~N}_{4} \mathrm{O}_{3} \mathrm{~S}(\mathrm{M}+)$ 304; found $305(\mathrm{MH}+)$; HPLC $(\mathrm{A}, 364 \mathrm{~nm})=99.0 \%$.

IR (ATR) $v_{\max }\left(\mathbf{c m}^{-1}\right): 3484\left(v_{\mathrm{as}} \mathrm{NH}_{2}\right) ; 3367$ $\left(v_{\mathrm{s}} \mathrm{NH}_{2}\right) ; 3146(v \mathrm{NH}) ; 3034(\mathrm{vCH}) ; 2931\left(\mathrm{vCH}_{3}\right)$; $1623(v \mathrm{C}=\mathrm{O}) ; 1592(v \mathrm{C}=\mathrm{N}) ; 1548(\delta \mathrm{NH}) ; 1510$ $\left(v_{\text {as }} \mathrm{NO}_{2}\right) ; 1449(\mathrm{vCC}) ; 1381(\mathrm{vNH}) ; 1328\left(v_{\mathrm{s}} \mathrm{NO}_{2}\right)$.

${ }^{1}$ H NMR (200 MHz, DMSO-d6) $\delta$ (ppm): $2.04\left(\mathrm{~s}, 3 \mathrm{H}, \mathrm{CH}_{3}\right) ; 6.93\left(\mathrm{~s}, 2 \mathrm{H}, \mathrm{NH}_{2}\right) ; 7.33(\mathrm{~s}, 1 \mathrm{H}$, H5); 7.99 (d, 2H, J=8.73 Hz, H2' \& H6'); 8.11 (s, 
$1 \mathrm{H}, \mathrm{N}=\mathrm{CH}) ; 8.30$ (d, 2H, J=8.78 Hz, H3' \& H5'); 11.5 (s, 1H, CONH).

${ }^{13} \mathrm{C}$ NMR (50 MHz, DMSO-d6) $\delta$ (ppm): $12.8\left(\mathrm{CH}_{3}\right)$; 96.5 (C2); 124 (C3' \& C5'); 127 (C4); 128 (C2' \& C4'); 130 (C1'); 139 (C4'); 141 (C5); $147(\mathrm{C} 3) ; 156(\mathrm{~N}=\mathrm{CH}) ; 165(\mathrm{CONH})$.

(E)-3-amino-N'-(4-hydroxybenzylidene)-4methylthiophene-2-carbohydrazide (8d; LASSBio 1895)

Obtained after 2 hours of reaction between the key intermediate $10(0.15 \mathrm{~g} ; 0.87 \mathrm{mmol})$ and 4-hydroxybenzaldehyde ( $0.12 \mathrm{~g} ; 0.97 \mathrm{mmol})$ as a yellow crystalline solid. Yield 63.7\%; m.p. 233 ${ }^{\circ} \mathrm{C}$; MS (EI) m/z calcd for $\mathrm{C}_{13} \mathrm{H}_{13} \mathrm{~N}_{3} \mathrm{O}_{2} \mathrm{~S}(\mathrm{M}+) 275$; found $276(\mathrm{MH}+)$; HPLC $(\mathrm{A}, 342 \mathrm{~nm})=99.6 \%$.

IR (ATR) $\mathbf{v}_{\max }\left(\mathbf{c m}^{-1}\right): 3363\left(\mathrm{vNH}_{2}\right) ; 3058$ $(v \mathrm{NH}) ; 2941\left(\mathrm{vCH}_{3}\right) ; 1628(v \mathrm{C}=\mathrm{O}) ; 1610(v \mathrm{C}=\mathrm{N})$; $1584(\delta \mathrm{NH}) ; 1445(v \mathrm{CC}) ; 1393(v \mathrm{NH}) ; 1228$ $(\delta \mathrm{OH})$.

${ }^{1}$ H NMR (200 MHz, DMSO-d6) $\delta$ (ppm): $2.05\left(\mathrm{~s}, 3 \mathrm{H}, \mathrm{CH}_{3}\right) ; 7.33$ (s, 1H, H5); 7.99 (d, 2H, $\mathrm{J}=8.53 \mathrm{~Hz}, \mathrm{H} 2$ ' \& H6'); $8.12(\mathrm{~s}, 1 \mathrm{H}, \mathrm{N}=\mathrm{CH})$; 8.30 (d, 2H, J=8.51 Hz, H3' \& H5'); 11.5 (s, 1H, $\mathrm{CONH})$.

${ }^{13} \mathrm{C}$ NMR (50 MHz, DMSO-d6) $\delta$ (ppm): $12.9\left(\mathrm{CH}_{3}\right) ; 102$ (C2); 116 (C3' \& C5'); $126\left(\mathrm{C}^{\prime}\right.$ '); 128 (C4); 129 (C2' \& C4'); 132 (C5); 143 (C3); $152(\mathrm{~N}=\mathrm{CH}) ; 159\left(\mathrm{C}^{\prime}\right) ; 164(\mathrm{CONH})$.

(E)-4-((2-(3-amino-4-methylthiophene-2carbonyl)hydrazone)methyl)benzoic acid (8e; LASSBio 1873)

Obtained after 1 hour of reaction between the key intermediate $\mathbf{1 0}(0.30 \mathrm{~g} ; 1.75 \mathrm{mmol})$ and 4-formylbenzoic acid (0.29 $\mathrm{g} ; 1.85 \mathrm{mmol})$ as a yellow crystalline solid. Yield $89.5 \%$; m.p. 140 ${ }^{\circ} \mathrm{C}$; MS (EI) m/z calcd for $\mathrm{C}_{14} \mathrm{H}_{13} \mathrm{~N}_{3} \mathrm{O}_{3} \mathrm{~S}(\mathrm{M}+)$ 303; found $304(\mathrm{MH}+)$; HPLC $(\mathrm{A}, 342 \mathrm{~nm})=99.7 \%$.
IR (ATR) $v_{\text {max }}\left(\mathbf{c m}^{-1}\right): 3374\left(v^{N_{2}}\right) ; 3231$ $(v \mathrm{NH}) ; 2926\left(\mathrm{CCH}_{3}\right) ; 1698(v \mathrm{C}=\mathrm{O} \& \mathrm{vCOOH})$; $1590(v \mathrm{C}=\mathrm{O}) ; 1442(v \mathrm{CC}) ; 1384(v \mathrm{NH})$.

${ }^{1} \mathrm{H}$ NMR (200 MHz, DMSO-d6) $\delta$ (ppm): $2.04\left(\mathrm{~s}, 3 \mathrm{H}, \mathrm{CH}_{3}\right) ; 7.32$ (s, 1H, H5); $7.86(\mathrm{~d}, 2 \mathrm{H}$, $\mathrm{J}=7.87 \mathrm{~Hz}, \mathrm{H} 2$ ' \& H6'); 8.01 (d, 2H, J=7.91 Hz, H3' \& H5'); 8.08 (s, 1H, N=CH); $11.4(\mathrm{~s}, 1 \mathrm{H}$, $\mathrm{CONH}) ; 13.0$ (s, 1H, COOH).

${ }^{13}$ C NMR (50 MHz, DMSO-d6) $\boldsymbol{\delta}$ (ppm): 12.9 $\left(\mathrm{CH}_{3}\right) ; 96.9$ (C2); 127 (C2'\& C6'); 127 (C4); 130 (C3'\& C5'); 130 (C1'); 131 (C4'); 139 (C5); 141 (C3); $156(\mathrm{~N}=\mathrm{CH}) ; 165(\mathrm{CONH}) ; 167(\mathrm{COOH})$.

(E)-3-amino-N'-(4-(dimethylamino)benzylidene)4-methylthiophene-2-carbohydrazide (8f;

LASSBio 1888)

Obtained after 2 hours of reaction between the key intermediate $\mathbf{1 0}(0.20 \mathrm{~g} ; 1.16 \mathrm{mmol})$ and 4-(dimethylamino)benzaldehyde (0.19 g; 1.26 $\mathrm{mmol}$ ) as an orange crystalline solid. Yield $44.6 \%$; m.p. $164{ }^{\circ} \mathrm{C}$; MS (EI) m/z calcd for $\mathrm{C}_{15} \mathrm{H}_{18} \mathrm{~N}_{4} \mathrm{OS}$ $(\mathrm{M}+)$ 302; found $303(\mathrm{MH}+)$; HPLC (A, $364 \mathrm{~nm})$ $=97.7 \%$.

IR (ATR) $v_{\max }\left(\mathbf{c m}^{-1}\right): 3410\left(v_{\mathrm{as}} \mathrm{NH}_{2}\right) ; 3346$ $\left(v_{\mathrm{s}} \mathrm{NH}_{2}\right) ; 3299(v \mathrm{NH}) ; 2913(\mathrm{vCH} 3) ; 1593(\mathrm{vC}=\mathrm{O})$; 1443 (vCC); 1361 (vNH); $1185(v C N)$.

${ }^{1}$ H NMR (200 MHz, DMSO-d6) $\delta$ (ppm) (Figure S3): $2.05\left(\mathrm{~s}, 3 \mathrm{H}, \mathrm{CH}_{3}\right) ; 3.00(\mathrm{~s}, 6 \mathrm{H}$, $\left.\mathrm{N}\left(\mathrm{CH}_{3}\right)_{2}\right) ; 7.05$ (d, 2H, J=7.94 Hz; H3' \& H5'); 7.31 (s, 1H, H5); 7.66 (d, 2H, J=8.33 Hz, H2' \& H6'); 7.95 (s, 1H, N=CH); 11.1 (s, 1H, CONH).

${ }^{13} \mathrm{C}$ NMR (50 MHz, DMSO-d6) $\delta$ (ppm) (Figure S4): $12.9\left(\mathrm{CH}_{3}\right) ; 41.1\left(\mathrm{~N}_{\left.\left(\mathrm{CH}_{3}\right)_{2}\right) ; 98.8}\right.$ (C2); 114 (C3' \& C5'); 125 (C1'); 127 (C4); 128 (C2' \& C6'); 130 (C4); 142 (C3); 149 (C4'); 154 $(\mathrm{N}=\mathrm{CH}) ; 165(\mathrm{CONH})$. 
(E)-3-amino-N'-(4-methoxybenzylidene)-4methylthiophene-2-carbohydrazide (8g; LASSBio 1874)

Obtained after 2 hours of reaction between the key intermediate $\mathbf{1 0}(0.20 \mathrm{~g} ; 1.16 \mathrm{mmol})$ and 4-methoxybenzaldehyde $(0.17 \mathrm{~g} ; 0.16 \mathrm{~mL} ; 1.26$ mmol) as a yellow crystalline solid. Yield $76.0 \%$; m.p. $176{ }^{\circ} \mathrm{C}$; MS (EI) m/z calcd for $\mathrm{C}_{14} \mathrm{H}_{15} \mathrm{~N}_{3} \mathrm{O}_{2} \mathrm{~S}$ $(\mathrm{M}+)$ 289; found $290(\mathrm{MH}+)$; HPLC (A, $342 \mathrm{~nm})$ $=99.6 \%$.

IR (ATR) $\mathbf{v}_{\max }\left(\mathbf{c m}^{-1}\right): 3464$ (vasNH2); 3397 (vsNH2); $3302(v \mathrm{NH}) ; 3136(\mathrm{vCH}) ; 2926(\mathrm{vCH} 3)$; $1608(v \mathrm{C}=\mathrm{O}) ; 1591(v \mathrm{C}=\mathrm{N}) ; 1555(\delta \mathrm{NH}) ; 1441$ (vCC); $1386(v \mathrm{NH}) ; 1249$ (vCOC).

${ }^{1}$ H NMR (200 MHz, DMSO-d6) $\delta$ (ppm): 2.03 (s, 3H, CH3); 3.79 (s, 3H, OCH3); 6.83 (s, 2H, NH2); 7.02 (d, 2H, J=8.29 Hz, H3' \& H5'); 7.29 (s, 1H, H5); 7.70 (d, 2H, J=8.16 Hz, H2' \& H6'); 7.96 $(\mathrm{s}, 1 \mathrm{H}, \mathrm{N}=\mathrm{CH}) ; 11.1(\mathrm{~s}, 1 \mathrm{H}, \mathrm{CONH})$.

${ }^{13}$ C NMR (50 MHz, DMSO-d6) $\delta$ (ppm): 12.9 (CH3); 55.3 (OCH3); 102 (C2); 114 (C3' \& C5'); 127 (C1'); 128 (C4); 129 (C2' \& C4'); 130 (C5); 143 (C3); $151(\mathrm{~N}=\mathrm{CH}) ; 161\left(\mathrm{C}^{\prime}\right)$; $164(\mathrm{CONH})$.

(E)-3-amino-N'-(4-isopropylbenzylidene)-4methylthiophene-2-carbohydrazide ( $8 \boldsymbol{h} ;$ LASSBio 1892)

Obtained after 0.5 hour of reaction between the key intermediate $\mathbf{1 0}(0.25 \mathrm{~g} ; 1.46 \mathrm{mmol})$ and 4-isopropylbenzaldehyde (0.24 g; $0.24 \mathrm{~mL} ; 1.56$ mmol) as a yellow crystalline solid. Yield $81.5 \%$; m.p. $169{ }^{\circ} \mathrm{C}$; MS (EI) m/z calcd for $\mathrm{C}_{16} \mathrm{H}_{19} \mathrm{~N}_{3} \mathrm{OS}$ $(\mathrm{M}+)$ 301; found $302(\mathrm{MH}+)$; HPLC (B, $342 \mathrm{~nm})$ $=99.2 \%$.

IR (ATR) $v_{\max }\left(\mathbf{c m}^{-1}\right): 3451\left(v_{\mathrm{as}} \mathrm{NH}_{2}\right) ; 3332$ $\left(v_{\mathrm{s}} \mathrm{NH}_{2}\right) ; 2958\left(\mathrm{vCH}_{3}\right) ; 1634(\mathrm{vC}=\mathrm{O}) ; 1600(\mathrm{vC}=\mathrm{N})$; $1551(\delta \mathrm{NH}) ; 1449(\mathrm{vCC}) ; 1381(\mathrm{vNH})$.

${ }^{1} \mathrm{H}$ NMR (200 MHz, DMSO-d6) $\delta$ (ppm) (Figure S5): 1.21 (d, 6H, J=6.77 Hz, $\left.\mathrm{CH}\left(\mathrm{CH}_{3}\right)_{2}\right)$; $2.06\left(\mathrm{~s}, 3 \mathrm{H}, \mathrm{CH}_{3}\right) ; 2.90(\mathrm{~m}, 1 \mathrm{H}, \mathrm{J}=6.77 \mathrm{~Hz}$, $\left.\mathrm{C} \underline{\mathrm{H}}\left(\mathrm{CH}_{3}\right)_{2}\right)$; 7.25-7.40 (m, 3H, H5 \& H3' \& H5');
7.68 (d, 2H, J=7.87 Hz, H2' \& H6'); 8.02 (s, 1H, $\mathrm{N}=\mathrm{CH}) ; 11.23$ (s, 1H, CONH).

${ }^{13} \mathrm{C}$ NMR (50 MHz, DMSO-d6) $\delta$ (ppm) (Figure S6): $12.9\left(\mathrm{CH}_{3}\right) ; 23.6\left(\mathrm{CH}\left(\underline{\mathrm{CH}}_{3}\right)_{2}\right) ; 33.3$ $\left(\underline{\mathrm{CH}}\left(\mathrm{CH}_{3}\right)_{2}\right) ; 98.4$ (C2); 127 (C3' \& C5'); 127 (C2' \& C6'); 127 (C1'); 130 (C4); 132 (C5); 142 (C3); $150(\mathrm{~N}=\mathrm{CH}) ; 155\left(\mathrm{C}^{\prime}\right) ; 165(\mathrm{CONH})$.

(E)-3-amino-4-methyl-N'-(4-phenoxybenzylidene) thiophene-2-carbohydrazide (8i; LASSBio 1887)

Obtained after 2 hours of reaction between the key intermediate $\mathbf{1 0}(0.20 \mathrm{~g} ; 1.16 \mathrm{mmol})$ and 4-phenoxybenzaldehyde ( $0.25 \mathrm{~g} ; 0.22 \mathrm{~mL} ; 1.26$ mmol) as a yellow crystalline solid. Yield 92.1\%; m.p. $207{ }^{\circ} \mathrm{C}$; MS (EI) m/z calcd for $\mathrm{C}_{19} \mathrm{H}_{17} \mathrm{~N}_{3} \mathrm{O}_{2} \mathrm{~S}$ $(\mathrm{M}+)$ 351; found $352(\mathrm{MH}+)$; HPLC (B, $342 \mathrm{~nm})$ $=99.8 \%$.

IR (ATR) $\mathbf{v}_{\max }\left(\mathbf{c m}^{-1}\right): 3454(\operatorname{vasNH} 2) ; 3332$ (vsNH2); $3139(v \mathrm{NH}) ; 2924(v \mathrm{CH} 3) ; 1633(v \mathrm{C}=\mathrm{O})$; $1585(v \mathrm{C}=\mathrm{N}) ; 1552(\delta \mathrm{NH}) ; 1445(\mathrm{vCC}) ; 1382$ $(v \mathrm{NH}) ; 1242$ (vCOC).

${ }^{1}$ H NMR (200 MHz, DMSO-d6) $\delta$ (ppm) (Figure S7): 2.03 (s, 3H, CH3); 6.80 (s, 2H, NH2); 7.07 (m, 4H, H3' \& H5' \& H2" \& H6"); 7.19 (t, $1 \mathrm{H}, \mathrm{J}=7.43 \mathrm{~Hz}, \mathrm{H} 4$ ') 7.27 (s, 1H, H5); 7.42 (t, 2H, J=8.27 Hz, H3" \& H5"); 7.77 (d, 2H, J=8.55 $\mathrm{Hz}, \mathrm{H} 2$ ' \& H6'); 8.01 (s, 1H, N=CH); 11.12 (s, 1H, $\mathrm{CONH}$ ) .

${ }^{13}$ C NMR (50 MHz, DMSO-d6) $\delta$ (ppm) (Figure S8): 13.0 (CH3); 97.2 (C2); 119 (C2" \& C4'); 119 (C3' \& C5'); 124 (C4”); 127 (C4 \& C1'); 129 (C2'\& C6'); 130 (C5); 130 (C3" \& C5"); 142 (C3); $156(\mathrm{~N}=\mathrm{CH}) ; 156$ (C4'); 158 (C1'”); 165 (CONH).

(E)-3-amino- $N$ '-(biphenyl-4-ylmethylene)-4methylthiophene-2-carbohydrazide (8j; LASSBio 1875)

Obtained after 3 hours of reaction between the key intermediate 10 (0.20 g; $1.16 \mathrm{mmol})$ and biphenyl4-carbaldehyde $(0.23 \mathrm{~g} ; 1.26 \mathrm{mmol})$ as a yellow 
crystalline solid. Yield 95.1\%; m.p. $217{ }^{\circ} \mathrm{C}$; MS (EI) $\mathrm{m} / \mathrm{z}$ calcd for $\mathrm{C}_{19} \mathrm{H}_{17} \mathrm{~N}_{3} \mathrm{OS}(\mathrm{M}+)$ 335; found $336(\mathrm{MH}+)$; HPLC (B, $342 \mathrm{~nm})=99.8 \%$.

IR (ATR) $\mathbf{v}_{\max }\left(\mathbf{c m}^{-1}\right): 3351$ (vasNH2); 2832 $(v \mathrm{CH}) ; 1622(v \mathrm{C}=\mathrm{O}) ; 1552(\mathrm{vsNO}) ; 1484$ (vCC); 1346 (vasNO2); 1372 (vNH).

${ }^{1}$ H NMR (200 MHz, DMSO-d6) $\delta$ (ppm) (Figure S9): 2.05 (s, 3H, CH3); 7.30-7.55 (m, 4H, H5 \& H3" \& H4" \& H5"); 7.65-7.95 (m, 6H; H2' \& H3' \& H5' \& H6' \& H2" \& H6"); 8.07 (s, 1H, $\mathrm{N}=\mathrm{CH}) ; 11.3(\mathrm{~s}, 1 \mathrm{H}, \mathrm{CONH})$.

${ }^{13} \mathrm{C}$ NMR (50 MHz, DMSO-d6) $\delta$ (ppm) (Figure S10): 13.0 (CH3); 97.1 (C2); 127 (C2” \& C6"); 127 (C3' \& C5' \& C4"); 128 (C2' \& C6'); 128 (C4); 129 (C3" \& C5”); 130 (C1'); 134 (C5); 139 (C1'); 141 (C4'); 142 (C3); 156 (N=CH); 165 (CONH).

(E)-3-amino-4-methyl-N'-(naphthalen-1ylmethylene)thiophene-2-carbohydrazide (8k; LASSBio 1877)

Obtained after 3.5 hours of reaction between the key intermediate $\mathbf{1 0}(0.20 \mathrm{~g} ; 1.16 \mathrm{mmol})$ and 1-naphthaldehyde $(0.20 \mathrm{~g} ; 1.26 \mathrm{mmol})$ as a yellow crystalline solid. Yield 89.5\%; m.p. $247{ }^{\circ} \mathrm{C}$; MS (EI) $\mathrm{m} / \mathrm{z}$ calcd for $\mathrm{C}_{17} \mathrm{H}_{15} \mathrm{~N}_{3} \mathrm{OS}(\mathrm{M}+) 309$; found $310(\mathrm{MH}+)$; HPLC $(\mathrm{B}, 342 \mathrm{~nm})=98.9 \%$.

IR (ATR) $\mathbf{v}_{\text {max }}\left(\mathbf{c m}^{-1}\right): 3472$ (vasNH2); 3349 (vsNH2); $2923(v \mathrm{CH} 3) ; 1622(v \mathrm{C}=\mathrm{O}) ; 1602$ $(v \mathrm{C}=\mathrm{N}) ; 1546(\delta \mathrm{NH}) ; 1460(v \mathrm{CC}) ; 1389(v \mathrm{NH})$.

${ }^{1}$ H NMR (200 MHz, DMSO-d6) $\delta$ (ppm) (Figure S11): 2.06 (s, 3H, CH3); 6.89 (s, 2H, NH2); 7.35 (s, 1H, H5); 7.50-7.60 (m, 2H, H2' \& H3'); 7.85-7.03 (m, 3H, H4' \& H6' \& H7'); 8.07 (s, $1 \mathrm{H}, \mathrm{N}=\mathrm{CH}$ ); 8.09-8.25 (m, 2H, H5' \& H8'); 11.3 (s, $1 \mathrm{H}, \mathrm{CONH})$.

${ }^{13} \mathrm{C}$ NMR (50 MHz, DMSO-d6) $\delta$ (ppm) (Figure S12): 12.9 (CH3); 97.0 (C2); 123 (C8'); 127 (C2'); 127 (C3'); 127 (C6'); 128 C7'); 128 (C4'); 128 (C5'); 128 (C8'a); 130 (C4'a); 132
(C4); 133 (C1'); 133 (C5); 142 (C3); $156(\mathrm{~N}=\mathrm{CH})$; $165(\mathrm{CONH})$.

(E)-3-amino-4-methyl-N'-(naphthalen-2-

ylmethylene)thiophene-2-carbohydrazide (8l; LASSBio 1889)

Obtained after 1.5 hours of reaction between the key intermediate $10(0.20 \mathrm{~g} ; 1.16 \mathrm{mmol})$ and 2-naphthaldehyde $(0.20 \mathrm{~g} ; 1.26 \mathrm{mmol})$ as a yellow crystalline solid. Yield 95.5\%; m.p. $248{ }^{\circ} \mathrm{C}$; MS (EI) $\mathrm{m} / \mathrm{z}$ calcd for $\mathrm{C}_{17} \mathrm{H}_{15} \mathrm{~N}_{3} \mathrm{OS}(\mathrm{M}+)$ 309; found $310(\mathrm{MH}+)$; HPLC (B, $342 \mathrm{~nm})=98.9 \%$.

IR (ATR) $\mathbf{v}_{\text {max }}\left(\mathbf{c m}^{-1}\right): 3472$ (vasNH2); 3349 $(v \mathrm{sNH} 2) ; 2923(v \mathrm{CH} 3) ; 1622(v \mathrm{C}=\mathrm{O}) ; 1602$ $(v \mathrm{C}=\mathrm{N}) ; 1546(\delta \mathrm{NH}) ; 1460(v \mathrm{CC}) ; 1389(v \mathrm{NH})$.

${ }^{1}$ H NMR (200 MHz, DMSO-d6) $\delta$ (ppm): 2.06 (s, 3H, CH3); 6.89 (s, 2H, NH2); 7.35 (s, 1H, H5); 7.48-7.65 (m, 2H, H3' \& H6'); 7.85-8.03 (m, $3 \mathrm{H}, \mathrm{H} 1$ ' \& H7' \& H8'); 8.07 (s, 1H, N=CH); 8.12 (d, 1H, J=8.31 Hz, H4'); 8.20 (m, 1H, H5'); 11.3 (s, 1H, CONH).

${ }^{13} \mathrm{C}$ NMR (50 MHz, DMSO-do) $\delta$ (ppm): 12.9 (CH3); 97.0 (C2); 123 (C3'); 127 (C1'); 127 (C6'); 127 (C7'); 128 (C5'); 128 (C8'); 128 (C4'); 129 (C4'a); 130 (C8'a); 132 (C4); 133 (C2'); 133 (C5); $142(\mathrm{C} 3) ; 156(\mathrm{~N}=\mathrm{CH}) ; 165(\mathrm{CONH})$.

(E)-(2-((2-(3-amino-4-methylthiophene-2carbonyl)hydrazone)methyl) ferrocene $(\mathbf{8 m}$; LASSBio 1876)

Obtained after 0.5 hour of reaction between the key intermediate $\mathbf{1 0}(0.30 \mathrm{~g} ; 1.75 \mathrm{mmol})$ and ferrocenecarbaldehyde $(0.41 \mathrm{~g} ; 1.85 \mathrm{mmol})$ as a brown crystalline solid. Yield 93.1\%; m.p. $57^{\circ} \mathrm{C}$; MS (EI) m/z calcd for $\mathrm{C}_{17} \mathrm{H}_{17} \mathrm{FeN}_{3} \mathrm{OS}(\mathrm{M}+)$ 367; found $368(\mathrm{MH}+)$; $\operatorname{HPLC}(\mathrm{A}, 332 \mathrm{~nm})=99.2 \%$.

IR (ATR) $v_{\text {max }}\left(\mathbf{c m}^{-1}\right): 3427$ (vasNH2); 3312 (vsNH2); 3087 (vCH); $2919(v \mathrm{CH} 3) ; 1620(v \mathrm{C}=\mathrm{O})$; $1588(v \mathrm{C}=\mathrm{N}) ; 1547(\delta \mathrm{NH}) ; 1438(\mathrm{vCC}) ; 1384$ $(v \mathrm{NH})$. 
${ }^{1}$ H NMR (200 MHz, DMSO-d6) $\delta$ (ppm): 2.03 (s, 3H, CH3); 4.19 (s, 5H, H1" \& H2" \& H3" \& H4" \& H5"); 4.40 (s, 2H, H3' \& H4'); 4.69 (s, 2H, H2' \& H5'); 6.78 (s, 2H, NH2); 7.26 (s, 1H, $\mathrm{H} 5) ; 7.81(\mathrm{~s}, 1 \mathrm{H}, \mathrm{N}=\mathrm{CH}) ; 11.0(\mathrm{~s}, 1 \mathrm{H}, \mathrm{CONH})$.

${ }^{13} \mathrm{C}$ NMR (50 MHz, DMSO-d6) $\delta$ (ppm): 12.8 (CH3); 67.4 (C3' \& C4'); 68.9 (C1'" \& C2"' \& C3" \& C4" \& C5"); 69.7 (C2' \& C3'); 79.53 (C1'); 97.7 (C2); 127 (C4); 130 (C5); 142 (C3); $155(\mathrm{~N}=\mathrm{CH}) ; 164(\mathrm{CONH})$.

(E)-3-amino-N'-(furan-2-ylmethylene)-4-

methylthiophene-2-carbohydrazide (8n; LASSBio 1872)

Obtained after 0.5 hour of reaction between the key intermediate $\mathbf{1 0}(0.30 \mathrm{~g} ; 1.75 \mathrm{mmol})$ and furan2-carbaldehyde $(0.19 \mathrm{~g} ; 0.16 \mathrm{~mL} ; 1.85 \mathrm{mmol})$ as a brown crystalline solid. Yield 77.3\%; m.p. 178 ${ }^{\circ} \mathrm{C}$; MS (EI) m/z calcd for $\mathrm{C}_{11} \mathrm{H}_{11} \mathrm{~N}_{3} \mathrm{O}_{2} \mathrm{~S}(\mathrm{M}+)$ 249; found $250(\mathrm{MH}+)$; HPLC $(\mathrm{A}, 300 \mathrm{~nm})=99.6 \%$.

IR (ATR) $\boldsymbol{v}_{\max }\left(\mathbf{c m}^{-1}\right): 3464$ (vasNH2); 3327 (vsNH2); 3136 (vNH); 2916 (vCH3); 1617 $(v \mathrm{C}=\mathrm{O}) ; 1588(\mathrm{vC}=\mathrm{N}) ; 1547(\delta \mathrm{NH}) ; 1442(\mathrm{vCC})$; $1372(\mathrm{vNH})$.

${ }^{1}$ H NMR (200 MHz, DMSO-d6) $\delta$ (ppm): 2.02 (s, 3H, CH3); 6.50-6.95 (m, 4H, NH2 \& H3' \& H4'); 7.26 (s, 1H, H5); 7.83 (m, 1H, H5'); 7.94 (s, 1H, N=CH); 11.1 (s, 1H, CONH).

${ }^{13} \mathrm{C}$ NMR (50 MHz, DMSO-d6) $\delta$ (ppm): 13.2 (CH3); 97.4 (C2); 112 (C3'); 112 (C4'); 127 (C2'); 130 (C4); 132 (C5); 145 (C3); 150 (C5'); $156(\mathrm{~N}=\mathrm{CH}) ; 165(\mathrm{CONH})$.

(E)-3-amino-N'-(furan-3-ylmethylene)-4-

methylthiophene-2-carbohydrazide (8o; LASSBio 1880)

Obtained after 3 hours of reaction between the key intermediate $\mathbf{1 0}(0.21 \mathrm{~g} ; 1.22 \mathrm{mmol})$ and furan3-carbaldehyde $(0.17 \mathrm{~g} ; 0.15 \mathrm{~mL} ; 1.32 \mathrm{mmol})$ as a yellow crystalline solid. Yield 58.9\%; m.p. 179
${ }^{\circ} \mathrm{C}$; MS (EI) $\mathrm{m} / \mathrm{z}$ calcd for $\mathrm{C}_{11} \mathrm{H}_{11} \mathrm{~N}_{3} \mathrm{O}_{2} \mathrm{~S}(\mathrm{M}+)$ 249; found $250(\mathrm{MH}+)$; HPLC $(\mathrm{A}, 332 \mathrm{~nm})=99.2 \%$.

IR (ATR) $\mathbf{v}_{\max }\left(\mathbf{c m}^{-1}\right): 3471$ (vasNH2); 3349 (vsNH2); 3126 (vNH); 2927 (vCH3); 1629 $(v \mathrm{C}=\mathrm{O}) ; 1590(\mathrm{vC}=\mathrm{N}) ; 1550(\delta \mathrm{NH}) ; 1441(\mathrm{vCC})$; 1373 (vNH).

${ }^{1}$ H NMR (200 MHz, DMSO-d6) $\delta$ (ppm) (Figure S13): 2.03 (s, 3H, CH3); $6.87(\mathrm{~m}, 1 \mathrm{H}$, H4'); 7.26 (s, 1H, H5); 7.70-7.80 (m, 1H, H5'); 7.98 (s, 1H, N=CH); 8.06-8.10 (m, 1H, H2'); 11.2 (s, 1H, CONH).

${ }^{13} \mathrm{C}$ NMR (50 MHz, DMSO-d6) $\delta$ (ppm) (Figure S14): 12.9 (CH3); 98.0 (C2); 108 (C4'); 123 (C3'); 127 (C5'); 130 (C2'); 134 (C4); 144 (C5); $145(\mathrm{C} 3) ; 155(\mathrm{~N}=\mathrm{CH}) ; 165(\mathrm{CONH})$.

(E)-N'-((1H-pyrrol-2-yl)methylene)-3-amino-4methylthiophene-2-carbohydrazide (8p; LASSBio 1894)

Obtained after 3.5 hours of reaction between the key intermediate $\mathbf{1 0}(0.25 \mathrm{~g} ; 1.46 \mathrm{mmol})$ and $1 \mathrm{H}$-pyrrole-2-carbaldehyde ( $0.15 \mathrm{~g} ; 1.56 \mathrm{mmol})$ as a violet crystalline solid. Yield 42.4\%; m.p. 82.2 ${ }^{\circ} \mathrm{C}$; MS (EI) $\mathrm{m} / \mathrm{z}$ calcd for $\mathrm{C}_{11} \mathrm{H}_{12} \mathrm{~N}_{4} \mathrm{OS}(\mathrm{M}+)$ 248; found $249(\mathrm{MH}+)$; HPLC $(\mathrm{B}, 342 \mathrm{~nm})=99.2 \%$.

IR (ATR) $\mathbf{v}_{\text {max }}\left(\mathbf{c m}^{-1}\right): 3207(\mathrm{vNH}) ; 1644$ $(v \mathrm{C}=\mathrm{O}) ; 1592(\mathrm{vC}=\mathrm{N}) ; 1548(\delta \mathrm{NH}) ; 1470(\mathrm{vCC})$; 1304 (vNH).

${ }^{1}$ H NMR (200 MHz, DMSO-d6) $\delta$ (ppm): 2.02 (s, 3H, CH3); 6.10-6.20 (m, 1H, H4'); 6.456.55 (m, 1H, H3'); 6.87-6.95 (m, 1H, H5'); 7.22 (s, $1 \mathrm{H}, \mathrm{H} 5) ; 7.92$ (s, 1H, N=CH); 10.8-11.1 (m, 2H, $\mathrm{H} 1$ ' \& $\mathrm{CONH})$.

${ }^{13} \mathrm{C}$ NMR (50 MHz, DMSO-d6) $\delta$ (ppm): 12.9 (CH3); 98.2 (C2); 109 (C4'); 122 (C3'); 127 (C5'); 128 (C2'); 129 (C4); 135 (C5); 141 (C3); $156(\mathrm{~N}=\mathrm{CH}) ; 164(\mathrm{CONH})$. 
(E)-3-amino-4-methyl-N'-(thiophen-2ylmethylene)thiophene-2-carbohydrazide (8q; LASSBio 1886)

Obtained after 3.5 hours of reaction between the key intermediate $10(0.28 \mathrm{~g} ; 1.63 \mathrm{mmol})$ and thiophene-2-carbaldehyde $(0.20 \mathrm{~g} ; 0.17 \mathrm{~mL} ; 1.73$ $\mathrm{mmol}$ ) as a brown crystalline solid. Yield $86.4 \%$; m.p. $209{ }^{\circ} \mathrm{C}$; MS (EI) m/z calcd for $\mathrm{C}_{11} \mathrm{H}_{11} \mathrm{~N}_{3} \mathrm{OS}_{2}$ $(\mathrm{M}+)$ 265; found $266(\mathrm{MH}+)$; HPLC (A, $332 \mathrm{~nm})$ $=99.5 \%$.

IR (ATR) $v_{\max }\left(\mathbf{c m}^{-1}\right): 3465$ (vasNH2); 3331 (vsNH2); 3129 (vNH); 2922 (vCH3); 1617 $(v \mathrm{C}=\mathrm{O}) ; 1582(v \mathrm{C}=\mathrm{N}) ; 1541(\delta \mathrm{NH}) ; 1444(v \mathrm{CC})$; 1385 (vNH).

${ }^{1}$ H NMR (200 MHz, DMSO-d6) $\delta$ (ppm): 2.03 (s, 3H, CH3); 6.81 (s, 2H, NH2); 7.10 (t, 1H, $\mathrm{J}=3.92 \mathrm{~Hz}, \mathrm{H} 4$ '); 7.29 (s, 1H, H5); 7.39 (d, 1H, $\mathrm{J}=2.42 \mathrm{~Hz}, \mathrm{H3}$ '); 7.61 (d, 1H, J=4.63 Hz, H5'); $8.21(\mathrm{~s}, 1 \mathrm{H}, \mathrm{N}=\mathrm{CH}) ; 11.2(\mathrm{~s}, 1 \mathrm{H}, \mathrm{CONH})$.

${ }^{13} \mathrm{C}$ NMR (50 MHz, DMSO-d6) $\delta$ (ppm): 12.9 (CH3); 97.3 (C2); 127 (C4'); 128 (C5'); 128 (C3'); 130 (C4 \& C2'); 137 (C5); 139 (C3); 156 $(\mathrm{N}=\mathrm{CH}) ; 165(\mathrm{CONH})$.

\section{(E)-3-amino-4-methyl-N'-(thiophen-3-} ylmethylene)thiophene-2-carbohydrazide (8r; LASSBio 1878)

Obtained after 3.5 hours of reaction between the key intermediate $10(0.20 \mathrm{~g} ; 1.16 \mathrm{mmol})$ and thiophene3-carbaldehyde (0.14 g; $0.11 \mathrm{~mL} ; 1.26 \mathrm{mmol})$ as a dark yellow crystalline solid. Yield 75.1\%; m.p. $187{ }^{\circ} \mathrm{C}$; MS (EI) m/z calcd for $\mathrm{C}_{11} \mathrm{H}_{11} \mathrm{~N}_{3} \mathrm{OS}_{2}(\mathrm{M}+)$ 265; found $266(\mathrm{MH}+)$; HPLC $(\mathrm{A}, 332 \mathrm{~nm})=99.0$ $\%$.

IR (ATR) $\boldsymbol{v}_{\max }\left(\mathbf{c m}^{-1}\right): 3457$ (vasNH2); 3330 (vsNH2); 3132 (vNH); 2922 (vCH3); 1621 $(v \mathrm{C}=\mathrm{O}) ; 1586(\mathrm{vC}=\mathrm{N}) ; 1542(\delta \mathrm{NH}) ; 1446(v \mathrm{CC})$; $1380(v \mathrm{NH})$.

${ }^{1}$ H NMR (200 MHz, DMSO-d6) $\delta$ (ppm): 2.03 (s, 3H, CH3); 6.83 (s, 2H, NH2); 7.28 (s, 1H,
H5); 7.56-7.68 (m, 2H, H4' \& H5'); 7.82-7.88 (m, 1H, H2'); 8.05 (s, 1H, N=CH); 11.1 (s, 1H, CONH).

${ }^{13} \mathrm{C}$ NMR (50 MHz, DMSO-d6) $\delta$ (ppm): 12.9 (CH3); 97.2 (C2); 125 (C4'); 127 (C5'); 127 (C2'); 127 (C3'); 130 (C4); 137 (C5); 138 (C3); $156(\mathrm{~N}=\mathrm{CH}) ; 165(\mathrm{CONH})$.

(E)-3-amino-4-methyl-N'-(pyridin-3-ylmethylene) thiophene-2-carbohydrazide (8s; LASSBio 1891)

Obtained after 0.5 hour of reaction between the key intermediate 10 (0.25 g; $1.46 \mathrm{mmol})$ and nicotinaldehyde $(0.17 \mathrm{~g} ; 0.15 \mathrm{~mL} ; 1.56 \mathrm{mmol})$ as a yellow crystalline solid. Yield 52.4\%; m.p. $266^{\circ} \mathrm{C}$ (degradation); MS (EI) m/z calcd for $\mathrm{C}_{12} \mathrm{H}_{12} \mathrm{~N}_{4} \mathrm{OS}$ $(\mathrm{M}+)$ 260; found $261(\mathrm{MH}+)$; HPLC (A, $342 \mathrm{~nm})$ $=99.0 \%$.

IR (ATR) $\mathbf{v}_{\text {max }}\left(\mathbf{c m}^{-1}\right): 3429$ (vasNH2); 3327 (vsNH2); $3064(v \mathrm{NH}) ; 3012(\mathrm{vCH}) ; 2923(v \mathrm{CH} 3)$; $1607(v \mathrm{C}=\mathrm{O}) ; 1574(v \mathrm{C}=\mathrm{N}) ; 1538(\delta \mathrm{NH}) ; 1444$ $(v \mathrm{CC}) ; 1378(\mathrm{vNH})$.

${ }^{1}$ H NMR (200 MHz, DMSO-d6) $\delta$ (ppm): 2.04 (s, 3H, CH3); 7.34 (s, 1H, H5); 7.86 (t, 1H, $\left.\mathrm{J}=6.74 \mathrm{~Hz}, \mathrm{H} 5^{\prime}\right) ; 8.12(\mathrm{~s}, 1 \mathrm{H}, \mathrm{N}=\mathrm{CH}) ; 8.56(\mathrm{~d}, 1 \mathrm{H}$, $\mathrm{J}=7.80 \mathrm{~Hz}, \mathrm{H} 4$ '); 8.76 (d, 1H, J=4.50 Hz; H6'); 9.04 (s, 1H, H2'); 11.6 (s, 1H, CONH).

${ }^{13} \mathrm{C}$ NMR (50 MHz, DMSO-d6) $\delta$ (ppm): 12.9 (CH3); 96.6 (C2); 126 (C5'); 127 (C4); 130 (C5); 133 (C3'); 137 (C3); 139 (C4'); 143 (C2'); $144\left(\mathrm{C}^{\prime}\right) ; 156(\mathrm{~N}=\mathrm{CH}) ; 165(\mathrm{CONH})$.

(E)-3-amino-4-methyl-N'-(pyridin-4-ylmethylene) thiophene-2-carbohydrazide (8t; LASSBio 1893)

Obtained after 0.5 hour of reaction between the key intermediate $10(0.30 \mathrm{~g} ; 1.75 \mathrm{mmol})$ and isonicotinaldehyde $(0.21 \mathrm{~g} ; 0.18 \mathrm{~mL} ; 1.85 \mathrm{mmol})$ as a yellow crystalline solid. yield $93.1 \%$; m.p. $286^{\circ} \mathrm{C}$ (degradation); MS (EI) m/z calcd for $\mathrm{C}_{12} \mathrm{H}_{12} \mathrm{~N}_{4} \mathrm{OS}$ $(\mathrm{M}+)$ 260; found $261(\mathrm{MH}+)$; HPLC (A, $342 \mathrm{~nm})$ $=99.4 \%$. 
IR (ATR) $\mathbf{v}_{\text {max }}\left(\mathbf{c m}^{-1}\right): 3416$ (vasNH2); 3307 $(v \mathrm{sNH} 2) ; 3084(v \mathrm{NH}) ; 1598(v \mathrm{C}=\mathrm{O}) ; 1572(v \mathrm{C}=\mathrm{N})$; $1548(\delta \mathrm{NH}) ; 1446(v \mathrm{CC}) ; 1356(\mathrm{vNH})$.

${ }^{1}$ H NMR (200 MHz, DMSO-d6) $\delta$ (ppm): 2.05 (s, 3H, CH3); 7.38 (s, 1H, H5); 8.16 (s, 1H, $\mathrm{N}=\mathrm{CH}) ; 8.21$ (d, 2H, J=6.69 Hz, H3' \& H5'); 8.89 (d, 2H, J=6.65 Hz, H2' \& H6'); 12.0 (s, 1H, $\mathrm{CONH})$.

${ }^{13}$ C NMR (50 MHz, DMSO-d6) $\delta$ (ppm): 12.9 (CH3); 95.9 (C2); 123 (C3'\& C5'); 127 (C4); 131 (C5); 137 (C3); 143 (C2’ \& C6'); 149 (C4'); $157(\mathrm{~N}=\mathrm{CH}) ; 165(\mathrm{CONH})$.

\section{ACKNOWLEDGMENTS}

The authors would like to thank the Conselho Nacional de Desenvolvimento Científico e Tecnológico (CNPq - BR), the Baden-Württemberg Stiftung (DE), the Fundação Carlos Chagas Filho de Amparo à Pesquisa do Estado do Rio de Janeiro (FAPERJ - BR) and Instituto Nacional de Ciência e Tecnologia de Fármacos e Medicamentos (INCTINOFAR - BR, Grant CNPq 573.564/2008-6 and FAPERJ E-26/170.020/2008) for fellowship and financial support.

\section{REFERENCES}

ABDEL-AZIZ HA, ABOUL-FADL T, AL-OBAID ARM, GHAZZALI M, AL-DHFYAN A AND CONTINI A. 2012. Design, synthesis and pharmacophoric model building of novel substituted nicotinic acid hydrazones with potential antiproliferative activity. Arch Pharm Res 35: 1543-1552.

AL-NURI MA AND HUSEIN AI. 2011. Synthesis and Biological Activity of N-Heteroaromatic Substituted Thiophene-2- Carbohydrazides. J Chem Chem Eng 5: 648-651.

ANAND P, SHENOY R, PALMER JE, BAINES AJ, LAI RYK, ROBERTSON J, BIRD N, OSTENFELD T AND CHIZH BA. 2011. Clinical trial of the p38 MAP kinase inhibitor dilmapimod in neuropathic pain following nerve injury. Eur J Pain 15: 1040-1048.

AZIZIAN H, MOUSAVI Z, FARAJI H, TAJIK M, BAGHERZADEH K, BAYAT P, SHAFIEE A AND ALMASIRAD A. 2016. Arylhydrazone derivatives of naproxen as new analgesic and anti-inflammatory agents:
Design, synthesis and molecular docking studies. J Mol Graph Model 67: 127-136.

BARREIRO EJ, KÜMMERLE AE AND FRAGA CAM. 2011. The methylation effect in medicinal chemistry. Chem Rev 111: 5215-5246.

COELHO AA, EVANS J, EVANS I, KERN A AND PARSONS S. 2011. The TOPAS symbolic computation system. Powder Diffr 26: S22-S25.

COLLIER HO, DINNEEN LC, JOHNSON CA AND SCHNEIDER C. 1968. The abdominal constriction response and its suppression by analgesic drugs in the mouse. Br J Pharmacol Chemother 32: 295-310.

COSTA FN, DA SILVA TF, SILVA EMB, BARROSO RCR, BRAZ D, BARREIRO EJ, LIMA LM, PUNZO F AND FERREIRA FF. 2015. Structural feature evolution - from fluids to the solid phase - and crystal morphology study of LASSBio 1601: a cyclohexyl-N-acylhydrazone derivative. RSC Adv 5: 39889-39898.

COSTA FN, FERREIRA FF, DA SILVA TF, BARREIRO EJ, LIMA LM, BRAZ D AND BARROSO RC. 2013. Structure re-determination of LASSBio-294 - a cardioactive compound of the $\mathrm{N}$-acylhydrazone class - using X-ray powder diffraction data. Powder Diffr 28: S491-S509.

CUTSHALL NS ET AL. 2012. Novel 2-methoxyacylhydrazones as potent, selective PDE10A inhibitors with activity in animal models of schizophrenia. Bioorg Med Chem Lett 22: 5595-5599.

DA SILVA YKC, REYES CTM, RIVERA G, ALVES MA, BARREIRO EJ, MOREIRA MSA AND LIMA LM. 2014. 3-Aminothiophene-2-acylhydrazones: Nontoxic, analgesic and anti-inflammatory lead-candidates. Molecules 19: 8456-8471.

DAVID WIF, SHANKLAND K, VAN DE STREEK J, PIDCOCK E, MOTHERWELL WDS AND COLE JC. 2006. DASH: A program for crystal structure determination from powder diffraction data. J Appl Crystallogr 39: 910915.

DE FIGUEIREDO LP, IBIAPINO AL, DO AMARAL DN, FERRAZ LS, RODRIGUES T, BARREIRO EJ, LIMA LM AND FERREIRA FF. 2017. Structural characterization and cytotoxicity studies of different forms of a combretastatin A4 analogue. J Mol Struct 1147: 226234.

DUARTE CD, BARREIRO EJ AND FRAGA CAM. 2007. Privileged structures: a useful concept for the rational design of new lead drug candidates. Mini Rev Med Chem 7: 1108-1119.

EVANS BE ET AL. 1988. Methods for drug discovery: development of potent, selective, orally effective cholecystokinin antagonists. J Med Chem 31: 2235-2246.

GAGE JL ET AL. 2011. N-Acylhydrazones as inhibitors of PDE10A. Bioorg Med Chem Lett 21: 4155-4159. 
GOETTERT M, GRAESER R AND LAUFER SA. 2010. Optimization of a nonradioactive immunosorbent assay for p38alpha mitogen-activated protein kinase activity. Anal Biochem 406: 233-234.

GUW, WU R, QI S, GU C, SIF AND CHEN Z. 2012. Synthesis and antibacterial evaluation of new $\mathrm{N}$-acylhydrazone derivatives from dehydroabietic acid. Molecules 17: 46344650.

GUNDOGDU-HIZLIATESC,ALYURUKH,GOCMENTURK M, ERGUN Y AND CAVAS L. 2014. Synthesis of new ibuprofen derivatives with their in silico and in vitro cyclooxygenase-2 inhibitions. Bioorg Chem 52: 8-15.

HE H, XIA H, XIA Q, REN Y AND HE H. 2017. Design and optimization of $\mathrm{N}$-acylhydrazone pyrimidine derivatives as E. coli PDHc E1 inhibitors: Structure-activity relationship analysis, biological evaluation and molecular docking study. Bioorg Med Chem 25: 5652-5661.

HERNÁNDEZ-VÁZQUEZ E, SALGADO-BARRERA S, RAMÍREZ-ESPINOSA JJ, ESTRADA-SOTO S AND HERNÁNDEZ-LUIS F. 2016. Synthesis and molecular docking of $\mathrm{N}^{\prime}$-arylidene-5-(4-chlorophenyl)1 -(3,4-dichlorophenyl)-4-methyl-1H-pyrazole-3carbohydrazides as novel hypoglycemic and antioxidant dual agents. Bioorg Med Chem 24: 2298-2306.

HERNÁNDEZ P, ROJAS R, GILMAN RH, SAUVAIN M, LIMA LM, BARREIRO EJ, GONZÁLEZ M AND CERECETTO H. 2013. Hybrid furoxanyl $\mathrm{N}$-acylhydrazone derivatives as hits for the development of neglected diseases drug candidates. Eur J Med Chem 59: 64-74.

JAGTAP VA, AGASIMUNDIN YS, JAYACHANDRAN E AND SATHE BS. 2011. In vitro anti-inflammatory activity of 2-amino-3-(substituted benzylidinecarbohydrazide)4,5,6,7-tetrahydrobenzothiophenes. J Pharm Res 4: 378379.

JIN Y, TAN Z, HE M, TIAN B, TANG S, HEWLETT I AND YANG M. 2010. SAR and molecular mechanism study of novel acylhydrazone compounds targeting HIV-1 CA. Bioorg Med Chem 18: 2135-2140.

JONES AM. 2017. Privileged Structures and Motifs (Synthetic and Natural Scaffolds). In: Comprehensive Medicinal Chemistry III. Elsevier, Oxford, UK, p. 116-152.

KHALIL NA, AHMED EM, MOHAMED KO AND ZAITONE SAB. 2013. Synthesis of new nicotinic acid derivatives and their evaluation as analgesic and antiinflammatory agents. Chem Pharm Bull 61: 933-940.

KÜMMERLE AE ET AL. 2009. Studies towards the identification of putative bioactive conformation of potent vasodilator arylidene $\mathrm{N}$-acylhydrazone derivatives. Eur J Med Chem 44: 4004-4009.

LACERDA RB, DA SILVA LL, DE LIMA CK, MIGUEZ E, MIRANDA AL, LAUFER SA, BARREIRO EJ AND
FRAGA CA. 2012. Discovery of novel orally active antiinflammatory N-phenylpyrazolyl-N-glycinyl-hydrazone derivatives that inhibit TNF-alpha production. PLoS ONE 7: e46925.

LI L, ZHANG Y, ZHANG J AND ZHENG A. 2013. Preparation method of articaine hydrochloride CN102060840 B.

LIN X, WANG M, ZHANG J AND XU R. 2014. p38 MAPK: a potential target of chronic pain. Curr Med Chem 21: 4405-4418.

MOLDOVAN CM, ONIGA O, PÂRVU A, TIPERCIUC B, VERITE P, PÎRNǍU A, CRIŞAN O, BOJIŢĂ M AND POP R. 2011. Synthesis and anti-inflammatory evaluation of some new acyl-hydrazones bearing 2-aryl-thiazole. Eur J Med Chem 46: 526-534.

OZADALI K, OZKANLI F, JAIN S, RAO PPN AND VELAZQUEZ-MARTINEZ CA. 2012. Synthesis and biological evaluation of isoxazolo[4,5-d]pyridazin-4$(5 \mathrm{H})$-one analogues as potent anti-inflammatory agents. Bioorg Med Chem 20: 2912-2922.

PALACE-BERL F, JORGE SD, PASQUALOTO KFM, FERREIRA AK, MARIA DA, ZORZI RR, DE SÁ BORTOLOZZO L, LINDOSO JAL AND TAVARES LC. 2013. 5-Nitro-2-furfuriliden derivatives as potential anti-Trypanosoma cruzi agents: Design, synthesis, bioactivity evaluation, cytotoxicity and exploratory data analysis. Bioorg Med Chem 21: 5395-5406.

PALLA G, PELIZZI C AND PREDIERI G. 1982. Conformational study on N-acylhydrazones of aromatic aldehydes by NMR spectroscopy. Gazz Chim Ital 112: 339-341.

TIPERCIUC B, PÂRVU A, TAMAIAN R, NASTASĂ C, IONUŢ I AND ONIGA O. 2013. New anti-inflammatory thiazolyl-carbonyl-thiosemicarbazides and thiazolylazoles with antioxidant properties as potential iNOS inhibitors. Arch Pharm Res 36: 702-714.

ÜNSAL-TAN O, ÖZDEN K, RAUK A AND BALKAN A. 2010. Synthesis and cyclooxygenase inhibitory activities of some N-acylhydrazone derivatives of isoxazolo[4,5-d] pyridazin-4(5H)-ones. Eur J Med Chem 45: 2345-2352.

ZARUBIN T AND HAN J. 2005. Activation and signaling of the p38 MAP kinase pathway. Cell Res 15: 11-18.

ZHAI X, HUANG Q, JIANG N, WU D, ZHOU H AND GONG P. 2013. Discovery of hybrid dual N-acylhydrazone and diaryl urea derivatives as potent antitumor agents: Design, synthesis and cytotoxicity evaluation. Molecules 18: 2904-2923.

\section{SUPPLEMENTARY MATERIAL}

Figures: S1-S14. 